\title{
The effect of photochemical ageing and initial precursor concentration on the composition and hygroscopic properties of $\beta$-caryophyllene secondary organic aerosol
}

\author{
M. R. Alfarra ${ }^{1,2}$, J. F. Hamilton ${ }^{3}$, K. P. Wyche ${ }^{4}$, N. Good ${ }^{1, *}$, M. W. Ward ${ }^{3}$, T. Carr ${ }^{4}$, M. H. Barley ${ }^{1}$, P. S. Monks ${ }^{4}$, \\ M. E. Jenkin ${ }^{5}$, A. C. Lewis ${ }^{6}$, and G. B. McFiggans ${ }^{1}$ \\ ${ }^{1}$ Centre for Atmospheric Science, School of Earth Atmospheric and Environmental Sciences, University of Manchester, UK \\ ${ }^{2}$ National Centre for Atmospheric Science (NCAS), School of Earth Atmospheric and Environmental Sciences, \\ University of Manchester, UK \\ ${ }^{3}$ Department of Chemistry, University of York, UK \\ ${ }^{4}$ Atmospheric Chemistry Group, Department of Chemistry, University of Leicester, UK \\ ${ }^{5}$ Atmospheric Chemistry Services, Okehampton, Devon, UK \\ ${ }^{6}$ National Centre for Atmospheric Science, University of York, Heslington, York, UK \\ *now at: Centre for Atmospheric and Instrumentation Research, University of Hertfordshire, UK
}

Correspondence to: M. R. Alfarra (rami.alfarra@manchester.ac.uk)

Received: 12 December 2011 - Published in Atmos. Chem. Phys. Discuss.: 25 January 2012

Revised: 8 June 2012 - Accepted: 3 July 2012 - Published: 24 July 2012

\begin{abstract}
The effect of photochemical ageing and initial precursor concentration on the composition and hygroscopic properties of secondary organic aerosol (SOA) formed during the chamber photo-oxidation of $\beta$-caryophyllene/ $\mathrm{NO}_{\mathrm{x}}$ mixtures were investigated. Nucleation of $\beta$-caryophyllene SOA particles occurred almost immediately after oxidation was initiated and led to the formation of fresh SOA with a relatively simpler composition than has been reported for monoterpenes. The SOA yield values ranged from 9.5$26.7 \%$ and $30.4-44.5 \%$ using a differential mobility particle sizer (DMPS) and an aerosol mass spectrometer (AMS) mass based measurements, respectively. A total of 20 compounds were identified in the SOA by LC-MS/MS, with the most abundant compounds identified as $\beta$-caryophyllonic acid and $\beta$-caryophyllinic acid/ $\beta$-nocaryophyllonic acid. The $\mathrm{O}: \mathrm{C}$ and $\mathrm{H}: \mathrm{C}$ elemental ratios of products identified in the condensed phase ranged from 0.20 to 1.00 and 1.00 to 2.00 , with average values of 0.39 and 1.58 , respectively. The increase in the $\mathrm{O}: \mathrm{C}$ ratio was associated with a decrease in the saturation concentration of the identified compounds. The compounds identified in the lower initial concentration experiments were more oxidised compared to those that were found to be more abundant in the higher initial concentration exper-
\end{abstract}

iments with average $\mathrm{O}: \mathrm{C}$ ratios of 0.51 and 0.27 , respectively. Photochemical ageing led to a more complex SOA composition with a larger contribution coming from lower molar mass, higher generation products, where both double bonds had been oxidised. This effect was more evident in the experiments conducted using the lower initial precursor concentration; a finding confirmed by the temporal behaviour of key organic mass fragment measured by an Aerosol Mass Spectrometer. Although the composition changed with both initial precursor concentration and ageing, this had no significant measurable effect on the hygroscopic properties of the SOA formed. The latter finding might have been influenced by the difference in pre-treatment of the semivolatilecontaining particles prior to their measurements.

\section{Introduction}

Despite being subject to fewer studies than monoterpenes $\left(\mathrm{C}_{10} \mathrm{H}_{16}\right)$, sesquiterpenes $\left(\mathrm{C}_{15} \mathrm{H}_{24}\right)$ are important hydrocarbons owing to their high aerosol yields (Griffin et al., 1999) and significant emissions from a wide variety of plant species (Arey et al., 1995; Helmig et al., 2007; Hansen and Seufert, 
2003). Sesquiterpenes are a class of biogenic hydrocarbons that comprise three isoprene $\left(\mathrm{C}_{5} \mathrm{H}_{10}\right)$ units and they have been observed in significant abundance in the atmospheres of many forests around the world (Arey et al., 1991; Helmig et al., 2007; Misztal et al., 2011; Goldstein and Galbally, 2007). Examples of sesquiterpenes observed in the forest atmosphere include compounds such as $\beta$-caryophyllene, $\alpha$ humulene and longifolene (Arey et al., 1991; König et al., 1995; Turlings and Tumlinson, 1992). Helmig et al. (2007) found that sesquiterpene emissions from a variety of pine tree species are as much as $29 \%$ of the monoterpene emissions. $\beta$-Caryophyllene is one of the most reactive and abundant sesquiterpenes (Hansen and Seufert, 2003; Helmig et al., 2007; Jaoui et al., 2007; Goldstein and Galbally, 2007). It has two double bonds (one endocyclic and one exocyclic) and has high reactivity towards ozone, hydroxyl and nitrate radicals. Under typical tropospheric conditions, the lifetime of $\beta$-caryophyllene with respect to $\mathrm{O}_{3}, \mathrm{NO}_{3}$ and $\mathrm{OH}$ has been estimated to be 2, 3 and $53 \mathrm{~min}$, respectively (Atkinson and Arey, 2003). Owing to the high molar mass of its oxidation products, $\beta$-caryophyllene has a high potential to contribute to secondary organic aerosol (SOA) mass in the atmosphere. The two reactive double bonds provide more than one point for potential chemical reactions to occur, leading to products with more functional groups and lower vapour pressures. Studies have shown that the aerosol yield (mass of SOA formed per mass of hydrocarbon consumed) of $\beta$-caryophyllene ranges (depending on experimental conditions) from 5 to $46 \%$ for ozonolysis and 17 to $68 \%$ for reactions with OH (Lee et al., 2006a; Griffin et al., 1999; Jaoui et al., 2003; Winterhalter et al., 2009; Ng et al., 2006). $\beta$-Caryophyllene SOA has also been shown to be an important contributor to $\mathrm{PM}_{2.5}$ mass in certain environments, e.g. boreal forests (Parshintsev et al., 2008), and in the southeastern United States (Jaoui et al., 2007; Kleindienst et al., 2007). More specifically it has been estimated that approximately $1-$ $10 \%$ of the organic aerosol mass in the southeastern and midwestern United States is made up of $\beta$-caryophyllene SOA (Kleindienst et al., 2007; Lewandowski et al., 2008).

Several smog chamber studies have investigated the chemical composition of secondary organic aerosol formed during dark, seedless $\beta$-caryophyllene ozonolysis experiments (Jaoui et al., 2003; Winterhalter et al., 2009; Li et al., 2011; Kanawati et al., 2008), with some quantitative yield information reported by Jaoui el al. (2003) and Li et al. (2011). Jaoui et al. (2003) presented a comprehensive $\beta$-caryophyllene ozonolysis study, which included identification and speciation of 17 compounds in both the gas and particulate phases and reported their total carbon yield to be $65 \%$ (for all identified compounds in both phases). The study identified $\beta$-caryophyllinic acid as a condensed phase tracer for $\beta$-caryophyllene oxidation. Jaoui and colleagues also reported in the same study that the main condensed phase products of $\beta$-caryophyllene ozonolysis were two semi-volatile ketoaldehydes; $\beta$-caryophyllene aldehyde (molar mass $=236 \mathrm{~g} \mathrm{~mol}^{-1}$ ) and $\beta$-nocaryophyllene aldehyde $\left(238 \mathrm{~g} \mathrm{~mol}^{-1}\right)$. Both compounds have low volatility and can readily form particles. In fact, the latter was positively identified and quantified in ambient samples collected at a forest in Finland (Parshintsev et al., 2008). Most recently Li et al. (2011) have argued that previous $\beta$-caryophyllene oxidation experiments were ozone limited and as a result focused mostly on first generation oxidation products. They conducted dark ozonolysis experiments of $\beta$-caryophyllene under conditions of excess ozone and reported 15 particlephase products. Of these, 9 were shown to be second generation products and were estimated to account for $90 \%$ of the mass of the 15 identified products. These results were consistent with an earlier study conducted by $\mathrm{Ng}$ et al. (2006) who observed (under both ozonolysis and photo-oxidation conditions) aerosol growth to continue after all of the precursor $\beta$-caryophyllene had been consumed, demonstrating the importance of second- or higher-generation reactions.

The studies cited above reported investigations of the speciated chemical composition of $\beta$-caryophyllene SOA formed under dark ozonolysis conditions. Recently, Chan et al. (2011) have studied SOA formation from the photooxidation of $\beta$-caryophyllene/ $\mathrm{NO}_{\mathrm{x}}$ mixtures in the presence of sulphuric acid/ammonium sulphate seeds. They reported detection of about 50 multifunctional species, containing acid, oxo, hydroxyl and nitro-oxy groups, and also a number of organosulphates; and found the SOA yield and composition were sensitive to aerosol acidity, providing evidence for acid-catalysed chemistry in the condensed phase. In the present paper, a study of the photo-oxidation of $\beta$ caryophyllene/ $\mathrm{NO}_{\mathrm{x}}$ mixtures is also reported, but with the aim of investigating the effect of photochemical ageing on the chemical composition and hygroscopic properties of the SOA, generated in the absence of a seed aerosol. In addition, the influence of the initial precursor mixing ratio on the physiochemical properties of the formed SOA is reported.

\section{Experimental methods}

\subsection{Reaction chamber}

Experiments were conducted in the photochemical aerosol reaction chamber at the University of Manchester. The design of the chamber and its operation will only be reported in brief here, as a full technical description of the facility can be found in a separate publication (McFiggans et al., 2012).

The Manchester aerosol chamber is run as a batch reactor where the composition of the gaseous precursors, oxidising environment, optional pre-existing seed, relative humidity and temperature are controlled. The chamber comprises an $18 \mathrm{~m}^{3}(3 \mathrm{~m}(H) \times 3 \mathrm{~m}(L) \times 2 \mathrm{~m}(W))$ FEP Teflon bag mounted on three horizontal rectangular aluminium frames. The central rigid frame is fixed, with the upper and lower frames free to move vertically, allowing the bag to expand 
and collapse as sample air is introduced and extracted. A series of halogen lamps and a $6 \mathrm{~kW}$ Xenon arc lamp are mounted on the inside of the enclosure housing the bag, which is coated with reflective "space blanket", serving to maximise the irradiance in the bag and to ensure even illumination. The combination of illumination has been tuned and evaluated to mimic the atmospheric actinic spectrum over the wavelength range $290-800 \mathrm{~nm}$, and has a maximum total actinic flux of $0.7 \times 10^{18}$ (photos $\mathrm{s}^{-1} \mathrm{~m}^{-2} \mathrm{~nm}^{-1}$ ) over the region $460-500 \mathrm{~nm}$. The calculated $j\left(\mathrm{O}^{1} \mathrm{D}\right)$ value during the reported experiments was $3.6 \times 10^{-5} \mathrm{~s}^{-1}(290-340 \mathrm{~nm})$.

The air supply into the chamber is dried and filtered for gaseous impurities and particles using a series of Purafil (Purafil Inc., USA), charcoal and HEPA (Donaldson Filtration) filters, prior to humidification with ultrapure deionised water. Precursors are introduced into the bag via injection into a heated glass bulb, which is continually flushed with a flow of filtered, high purity nitrogen (ECD grade, $99.997 \%$ ). The required concentration of $\mathrm{NO}_{\mathrm{x}}$ is controlled by injection of $\mathrm{NO}_{2}$ from a cylinder into the charge line.

Relative humidity $(\mathrm{RH})$ and temperature are measured at several points throughout the chamber (by dewpoint hygrometer and a series of cross-calibrated thermocouples and resistance probes), and are controlled by diverting air through the inlet humidification circuit when filling the bag and by controlling the setpoint of the air conditioning, which feeds the airspace between the bag and its enclosure. This mechanism is employed to control conditions throughout the experiment. Cycling between experiments is facilitated by full computer control and monitoring of key chamber conditions. Pre- and post-experiment cleaning processes consist of an overnight soaking at high mixing ratios of ozone (2-2.5 ppmV, supplied by a high capacity ozone generator), and a series of automatic fill/flush cycles with $3 \mathrm{~m}^{3} \mathrm{~min}^{-1}$ flow of scrubbed, dried and rehumidified air, achieved by control of electro-pneumatic valves. Each cycle takes approximately $12 \mathrm{~min}$ and cleaning is normally achieved after approximately 6 cycles.

\subsection{Experiment methodology}

$\beta$-caryophyllene SOA was formed in standard nucleation experiments, involving the photo-oxidation of $\beta$-caryophyllene (Aldrich, purity not specified) in the presence of $\mathrm{NO}_{\mathrm{x}}$. Identical experiments were repeated and stopped at different elapsed times after lights on, in this case after 2 and $6 \mathrm{~h}$. At the end of each experiment the majority of the air in the chamber was passed through a filter for the collection of SOA and subsequent off-line analysis. Experiments were carried out at two different nominal initial precursor mixing ratios of 50 and $250 \mathrm{ppbV}$ in order to study the effect of initial precursor concentration on SOA properties and composition. VOC measurements (described in Sect. 2.3) were made during several low concentration experiments and measured initial VOC mixing ratios are reported in Tables $1 \mathrm{a}$ and $\mathrm{b}$. However, measurements were only made during two of the higher initial concentration experiments and showed that approximately $140 \mathrm{ppbV}$ was present in the chamber at the start of each experiment. It is not possible, from the available data, to verify whether this was a result of (i) poor transfer of the VOC into the chamber at the higher concentration conditions which could have also affected all other similar experiments or (ii) injection problems specific to those two experiments. Therefore, the two different starting conditions will be referred to in the manuscript as "lower" and "higher" initial concentrations. An overview of the conditions used in each experiment is given in Tables 1a and b. A background level of around $10 \mathrm{ppbV}$ of $\mathrm{NO}$ was present in this study (subsequent experiments have achieved an NO background of around $1 \mathrm{ppbV})$.

\subsection{On-line measurements}

Real-time broad chemical characterisation of the SOA was made using a compact Time-of-Flight Aerosol Mass Spectrometer (cTOF-AMS, Aerodyne Research Inc., USA). A detailed description of the instrument, its operation and calibrations can be found elsewhere (Drewnick et al., 2005; Canagaratna et al., 2007). The instrument was operated in the standard configuration, taking both mass spectrum (MS) and particle-time-of-flight (PToF) data, and was calibrated for ionisation efficiency using $350 \mathrm{~nm}$ monodisperse ammonium nitrate particles. The vapouriser was set at approximately $600{ }^{\circ} \mathrm{C}$ and data was collected at a time resolution of $2 \mathrm{~min}$. A collection efficiency value of unity was applied to this data, based on evidence from a previous chamber study (Alfarra et al., 2006).

A Differential Mobility Particle Sizer (DMPS) was used to measure the aerosol number size distribution between $20 \mathrm{~nm}$ and $500 \mathrm{~nm}$ (Williams et al., 2007). The DMPS performed a complete mobility scan every $10 \mathrm{~min}$, which allowed adequate sampling time for each mobility size. The DMPS was composed of a Vienna-design differential mobility analyser (DMA) (Winklmayr et al., 1991), and a condensation particle counter (3010 CPC, TSI Inc., USA).

A Hygroscopicity Tandem Differential Mobility Analyser (HTDMA) was used to measure on-line size resolved water uptake at $90 \% \mathrm{RH}$. A technical description of the instrument was provided in other publications (Good et al., 2010a; $\mathrm{Cu}$ bison et al., 2006). Briefly, the HTDMA dries the aerosol sample to $<10 \%$ RH using a Nafion ${ }^{\circledR}$ drier (Perma Pure, MD-110-12, Toms River, NJ, USA). A DMA (BMI, Haywood, CA, USA) selects particles of a single mobility. In this work, diameters chosen were larger than the mode of the number size distribution, thus avoiding the sampling of a significant fraction of multi-charged particles. The sample is then humidified to $90 \% \mathrm{RH}$ using a humidifier, comprising a Gore-Tex ${ }^{\circledR}$ tube running through a controlled humid counter-flow of air. The humidified size selected sample is then passed through a residence coil for $15 \mathrm{~s}$. A second DMA (BMI, Haywood, CA, USA) and CPC (TSI, 3782) are then 
Table 1a. Initial experimental conditions including measured VOC mixing ratios and calculated SOA yields.

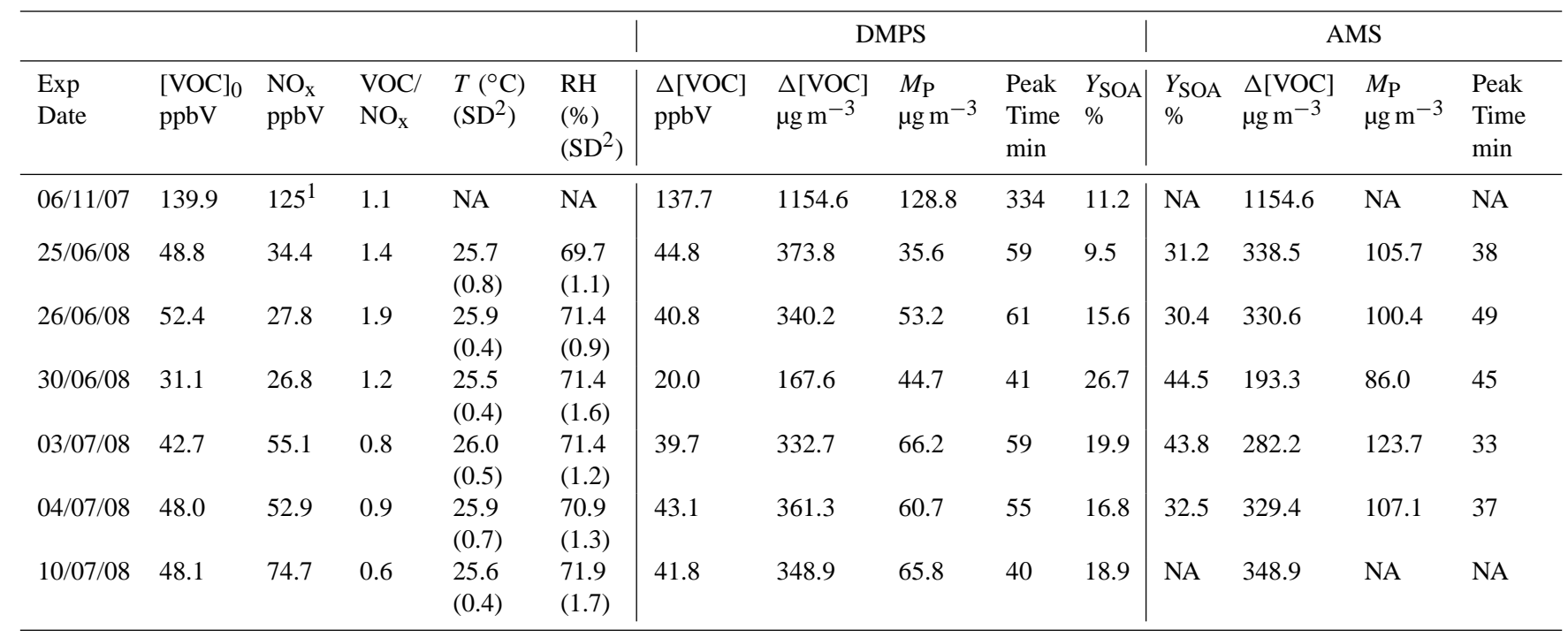

NA = No data available; ${ }^{1}$ Nominal concentration values estimated based on the amount introduced into the chamber without accounting for losses; ${ }^{2}$ Standard deviation.

Table 1b. Initial experimental conditions and peak mass concentrations for experiments where SOA yield values were not possible to calculate.

\begin{tabular}{|c|c|c|c|c|c|c|c|}
\hline Exp Date & $\begin{array}{l}{[\mathrm{VOC}]_{0}} \\
\mathrm{ppbV}\end{array}$ & $\begin{array}{l}\mathrm{NO}_{\mathrm{x}} \\
\mathrm{ppbV}\end{array}$ & $\begin{array}{l}\text { VOC/ } \\
\mathrm{NO}_{\mathbf{x}}\end{array}$ & $\begin{array}{l}T \\
\left({ }^{\circ} \mathrm{C}\right) \\
(\mathrm{SD})\end{array}$ & $\begin{array}{l}\mathrm{RH} \\
(\%) \\
(\mathrm{SD})\end{array}$ & $\begin{array}{l}\text { DMPS } \\
\text { Peak SOA } \\
\mu \mathrm{g} \mathrm{m}^{-3}\end{array}$ & $\begin{array}{l}\text { AMS Peak } \\
\text { SOA } \\
\mu \mathrm{g} \mathrm{m}^{-3}\end{array}$ \\
\hline 05/11/07 & 39.3 & $25^{*}$ & 1.6 & NA & NA & NA & NA \\
\hline 20/11/07 & 39.3 & $25^{*}$ & 1.6 & NA & NA & NA & NA \\
\hline $21 / 11 / 07$ & 144.2 & $125^{*}$ & 1.2 & NA & NA & NA & NA \\
\hline $12 / 03 / 08$ & $50^{*}$ & 33.6 & 1.5 & $\begin{array}{l}25.3 \\
(0.2)\end{array}$ & $\begin{array}{l}53.9 \\
(0.6)\end{array}$ & $>21.6$ & 69.7 \\
\hline 13/03/08 & $250^{*}$ & 116.8 & 2.1 & $\begin{array}{l}24.9 \\
(0.3)\end{array}$ & $\begin{array}{l}49.4 \\
(0.6)\end{array}$ & $>130.3$ & 303.7 \\
\hline 10/04/08 & $250^{*}$ & 130.3 & 1.9 & $\begin{array}{l}24.7 \\
(0.1)\end{array}$ & $\begin{array}{l}49.2 \\
(0.2)\end{array}$ & $>125.3$ & NA \\
\hline 16/04/08 & $250^{*}$ & 128.4 & 1.9 & $\begin{array}{l}26.1 \\
(0.3)\end{array}$ & $\begin{array}{l}44.4 \\
(0.7)\end{array}$ & 220.0 & 216.2 \\
\hline 23/04/08 & $50^{*}$ & 31.4 & 1.6 & $\begin{array}{l}25.4 \\
(0.3)\end{array}$ & $\begin{array}{l}53.4 \\
(0.7)\end{array}$ & 50.1 & 55.6 \\
\hline $24 / 04 / 08$ & $50^{*}$ & 28.2 & 1.8 & $\begin{array}{l}25.4 \\
(0.4)\end{array}$ & $\begin{array}{l}47.9 \\
(0.9)\end{array}$ & 65.6 & NA \\
\hline 28/05/08 & $250^{*}$ & 119.5 & 2.1 & $\begin{array}{l}28.4 \\
(1.0)\end{array}$ & $\begin{array}{l}57.5 \\
(2.6)\end{array}$ & 238.2 & 258.6 \\
\hline 29/05/08 & $50^{*}$ & 36.7 & 1.4 & $\begin{array}{l}23.8 \\
(0.9)\end{array}$ & $\begin{array}{l}75.2 \\
(1.5)\end{array}$ & 59.9 & 77.8 \\
\hline 05/06/08 & $50^{*}$ & 22.8 & 2.2 & $\begin{array}{l}23.4 \\
(0.5)\end{array}$ & $\begin{array}{l}75.3 \\
(1.2)\end{array}$ & NA & 51.6 \\
\hline
\end{tabular}

$\mathrm{NA}=$ No data available ${ }^{*}$ Nominal concentration values estimated based on the amount introduced into the chamber without accounting for losses. 
used to measure the size distribution of the humidified sample. The operating procedure of the HTDMA was validated by sampling ammonium sulphate and sodium chloride test aerosols, following the operating procedures described by Good et al. (2010a). The data was inverted using the method described by Gysel et al. (2009). The data from the HTDMA is reported in terms of the hygroscopic growth factor $\left(\mathrm{GF}_{D_{0}, \mathrm{RH}}\right)$, the wet particle diameter at a given $\mathrm{RH}$ divided by the particle's dry diameter $\left(D_{0}\right)$.

The cloud condensation nuclei $(\mathrm{CCN})$ activity of the particles was characterised using a continuous flow $\mathrm{CCN}$ counter (Droplet Measurement Technologies, USA) combined with a Vienna style DMA (Winklmayr et al., 1991) and a particle counter TSI 3010 CPC. The DMA was used to generate monodisperse aerosol in the size range between $20 \mathrm{~nm}$ and $500 \mathrm{~nm}$ dry diameter. These particles were directed in parallel to the CPC and CCN counters. The inlet flow in the CCN counter was $0.5 \mathrm{lpm}$ and it was operated at different supersaturations in the range between $0.07 \%$ and $1 \%$ for each particle size. The calibration and quality assurance procedures carried out for this setup is described in Good et al. (2010a). Using the instrumental set-up described above $\mathrm{CCN}$ and $\mathrm{CN}$ number size distributions were measured at $\Delta T$ 's equivalent to super-saturations between $0.07 \%$ and $1.0 \%$. The $\mathrm{CCN}$ and $\mathrm{CN}$ number size distributions were then inverted to account for charging efficiency and multiple charging (Good et al., 2010a). The inverted number size distributions were then used to calculate the activated fraction $(\mathrm{CCN} / \mathrm{CN})$ as a function of dry size. Sigmoidal functions were then fitted to the activation curves, from which the dry diameter at which $50 \%$ of the particles were activated was calculated. Given that the aerosol is internally mixed the diameter at which $50 \%$ of the particles activate is judged to be the dry diameter at which the particles are activated as $\mathrm{CCN}$ at the set-point supersaturation (Good et al., 2010b). $\kappa$-values are then derived from the $\mathrm{CCN}$ measurements on the chamber by iteratively finding $\kappa$ from the $\kappa$-Kohler equation (Petters and Kreidenweis, 2007) given that the critical super-saturation and dry diameter are known from the measurements.

$\mathrm{NO}$ and $\mathrm{NO}_{2}$ mixing ratios were measured using a chemiluminescence gas analyser (Model 42i, Thermo Scientific, MA, USA). Ozone was measured using a UV photometric gas detector (Model 49C, Thermo Scientific, MA, USA).

The gas phase organic compounds within the chamber were measured using Chemical Ionisation Reaction Time-ofFlight Mass Spectrometry (CIR-TOF-MS). This technique has been described in detail elsewhere (Wyche et al., 2007; Jenkin et al., 2012). The CIR-TOF-MS instrument comprises a bespoke, temperature controlled $\left(40^{\circ} \mathrm{C} \pm 1^{\circ} \mathrm{C}\right)$ radioactive $\left({ }^{241} \mathrm{Am}\right)$ ion source/drift tube assembly, coupled via a system of ion transfer optics to an orthogonal time-of-flight mass spectrometer (Kore Technology, UK). In this instance, hydrated hydronium ions $\left(\mathrm{H}_{3} \mathrm{O}^{+} \cdot\left(\mathrm{H}_{2} \mathrm{O}\right)\right)$, generated from a humidified $\mathrm{N}_{2}$ carrier gas (purity $=99.9999 \%$ ), were employed as the primary chemical ionisation reagent. Ion-molecule re- action between the analyte VOC/OVOC, M, and the hydrated hydronium ion will yield a protonated VOC/OVOC product ion $\left(\mathrm{MH}^{+}\right)$for mass spectrometric analysis, providing the analyte has a proton affinity greater than that of the water dimer $\left(808 \mathrm{~kJ} \mathrm{~mol}^{-1}\right)$. Depending on the energies involved and chemical structure of the VOC/OVOC analyte, the $\mathrm{MH}^{+}$product may undergo fragmentation to produce certain daughter ions. The CIR-TOF-MS was calibrated using various methods, including: (i) stepwise dilution and measurement of a commercially sourced gas standard (BOC Special Gases, UK); (ii) analysis of gas standards generated from permeation tubes (Eco-Scientific Ltd, UK and Vici Inc., USA) using a commercial calibration and humidification unit (Kintec, model 491) and (iii) analysis of 101 Teflon sample bags (SKC Inc. USA) following liquid injection of the target VOC/OVOC into a nitrogen matrix. Mass spectrometric data were recorded by the CIR-TOF-MS over the range 0 and $300 \mathrm{Da}$ with a time resolution of $1 \mathrm{~min}$. All mass spectra were normalised with respect to the reagent ion signal and were background subtracted.

\subsection{Off-line analysis of $\beta$-caryophyllene SOA}

Aerosol samples were collected onto pre-fired quartz filters, placed into clean glass vials sealed with parafilm and stored in a freezer at $-18^{\circ} \mathrm{C}$ until analysis. A bespoke filter holder was positioned in the chamber vent line to allow the entire chamber content to be sampled onto the filter in a few min at a nominal flow of $3 \mathrm{~m}^{3} \mathrm{~min}^{-1}$. Filter samples were analysed using a method described previously (Hamilton et al., 2008). Briefly; filter samples were extracted into $5 \mathrm{ml}$ of HPLC grade water. The sample vial was wrapped in foil to avoid any possible degradation and left for two hours. This was sonicated for one hour and the extraction was filtered using a $0.45 \mathrm{~mm}$ PVDF syringe filter (Whatman). Extracts were evaporated to dryness using a V10 vacuum solvent evaporator (Biotage, Sweden) at $30^{\circ} \mathrm{C}$ and the residue was redissolved in $1 \mathrm{ml}$ of a 50:50 solution of HPLC-MS grade water and methanol.

Liquid Chromatography Mass Spectrometry (LC-MS/MS) analysis was performed on the extracted sample using a HCT Plus ion trap mass spectrometer (Bruker Daltonics GmbH, Bremen, Germany) equipped with an Eclipse ODS-C 18 column with $5 \mu \mathrm{m}$ particle size (Agilent, $4.6 \mathrm{~mm} \times 150 \mathrm{~mm}$ ). Samples $(60 \mu \mathrm{l})$ were injected via an auto sampler (Agilent 1100 series) and a binary gradient elution was performed using (a): $0.1 \%$ formic acid in HPLC-MS grade water (100 to $40 \%$ over $40 \mathrm{~min}$, hold for $10 \mathrm{~min}$, return to starting conditions) and (b): HPLC grade methanol, at a flow rate of $0.6 \mathrm{mlpm}$. Electrospray ionisation (ESI) was carried out at $300^{\circ} \mathrm{C}$, with a nebuliser pressure of $70 \mathrm{psi}$ and nitrogen dry gas flow rate of $12 \mathrm{lpm}$. The mass spectrometer was used in both positive and negative ion mode, scanning from $\mathrm{m} / \mathrm{z} 50$ to 600. The automated MS/MS function from the Esquire software (Bruker Daltonics GmbH, Bremen, Germany) was 
used to fragment ions, where the two most abundant ions at each scan were subjected to collision-induced dissociation (CID).

\section{Results and discussion}

\section{$3.1 \beta$-caryophyllene SOA formation characteristics}

During all experiments conducted in this study, $\beta$ caryophyllene SOA was rapidly formed within a few minutes of the start of photochemistry (lights on), producing total particle number concentrations in the range of $25 \times 10^{3}$ to $35 \times 10^{3} \mathrm{p} / \mathrm{cc}$ and variable peak mass concentration depending on the initial conditions (see Tables 1a and b). The top panel in Fig. 1 shows the temporal profile of the decay of $\beta$-caryophyllene and the production of a first generation gas phase product (identified as $m / z$ 237). The bottom panel in the same figure shows the rapid formation of the corresponding particle number and mass concentrations.

Particle volume measurements obtained from the DMPS were multiplied by a $\beta$-caryophyllene SOA density factor of 1.3 (Bahreini et al., 2005; Varutbangkul et al., 2006) in order to provide the SOA mass concentrations formed during each experiment. Additionally, total mass concentrations were also obtained using the cTOF-AMS. Both sets of measurements are listed in Tables $1 \mathrm{a}$ and $\mathrm{b}$ together with those of $\beta$-caryophyllene and $\mathrm{NO}_{\mathrm{x}}$ mixing ratios. The DMPS results show that a peak SOA mass of $129-238 \mu \mathrm{g} \mathrm{m}^{-3}$ was achieved under the higher concentration conditions, whereas a peak of 36-66 $\mu \mathrm{g} \mathrm{m}^{-3}$ was achieved under the lower concentration conditions. On the other hand, the AMS measured higher peak SOA masses, in the range 216-304 $\mathrm{g} \mathrm{m} \mathrm{m}^{-3}$ and $52-124 \mu \mathrm{g} \mathrm{m}^{-3}$ during the higher and lower concentration experiments, respectively.

Using these mass values along with the corresponding quantity of $\beta$-caryophyllene reacted and Eq. (1), an SOA yield may be obtained:

$Y_{\mathrm{SOA}}=\frac{M_{\mathrm{P}}}{\Delta \mathrm{VOC}}$

Where: $Y_{\mathrm{SOA}}=$ SOA mass yield, $M_{\mathrm{P}}=$ peak SOA mass $\left(\mu \mathrm{g} \mathrm{m}^{-3}\right)$ and $\triangle \mathrm{VOC}=\beta$-caryophyllene reacted $\left(\mu \mathrm{g} \mathrm{m}^{-3}\right)$. Table 1a lists the SOA yields obtained for those experiments for which both gas and particle phase data were available. From inspection of Table 1a it can be seen that the DMPSbased SOA yield for the lower concentration experiments ranged from $9.5-26.7 \%$, and that a yield value of $11.2 \%$ was obtained for the single higher concentration experiment for which data was available. However, the AMS-based SOA yield values were a factor of 1.7-3.3 higher than those obtained using the DMPS measurements (ranging from 30.4$44.5 \%$ ). A possible explanation for the discrepancies between the DMPS and AMS mass measurements is the difference in pre-treatment of the semivolatile-containing particles prior to the instrumentation. The DMPS sample was
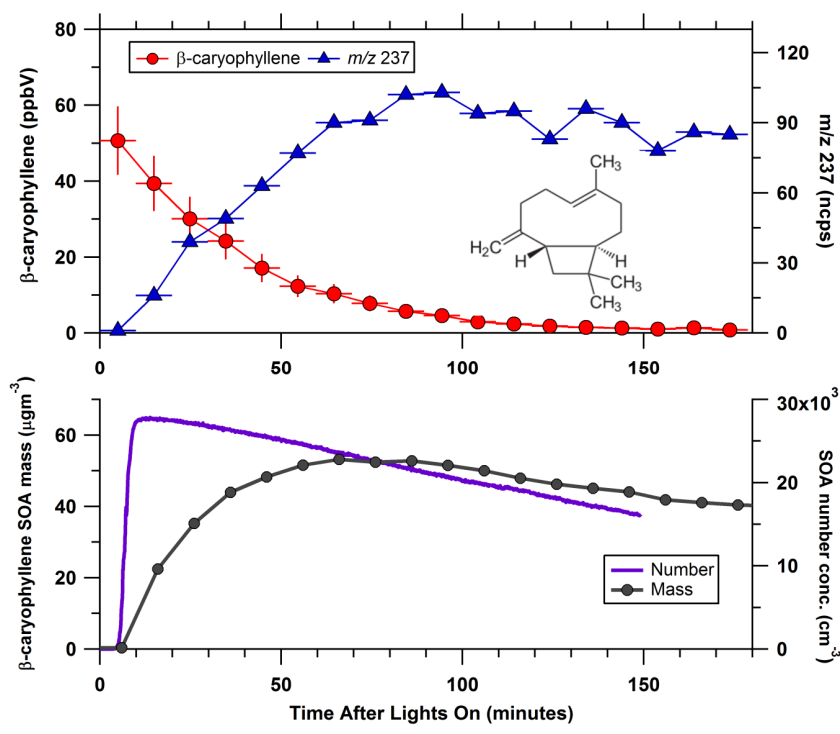

Fig. 1. Evolution of basic gas and condensed phase measurements during the photo-oxidation of $\beta$-caryophyllene. The SOA mass concentration shown in the bottom panel was measured using a differential mobility particle sizer (DMPS). The molecular structure of $\beta$-caryophyllene is shown in the top panel.

subjected to a dry sheath air $(\mathrm{RH}<10 \%)$, while the AMS sample was not dried. Section 3.5 provides further discussion of the possible presence of semi-volatile material in these samples. It should be noted that as no wall loss corrections were applied to the gas or particle phase data and as the semi-volatiles are believed to partition rapidly to the condensed phase, the SOA yields presented here constitute lower limit values (Matsunaga and Ziemann, 2010; Hamilton et al., 2011). Comprehensive wall loss characterisation for the Manchester chamber is an ongoing exercise.

Several other simulation chamber studies investigating $\beta$ caryophyllene photo-oxidation and ozonolysis under a range of different conditions have been published over recent years, giving a wide range of SOA yields, from 5 to $68 \%$ (Griffin et al., 1999; Jaoui et al., 2003; Lee et al., 2006b; Ng et al., 2006; Winterhalter et al., 2009). The values obtained from our work fall in the mid-lower region of this range, more in line with work performed by Winterhalter and colleagues, who reported (non-wall loss corrected) yields in the range 6-41\% for their ozonolysis experiments.

\section{2 $\beta$-caryophyllene SOA composition}

The filter extracts containing $\beta$-caryophyllene SOA were analysed using liquid chromatography coupled to ion-trap mass spectrometry in both positive and negative ionisation modes. Chromatographically separated compounds in all samples were studied using MS/MS product ion spectra and structures proposed based on previous literature, fragmentation patterns, known reaction mechanisms and comparison 
of spectral features to a large range of standard compounds (multifunctional acids, carbonyls, alcohols, esters, acetates). The proposed structures and retention times are shown in Table 2 . In some cases, only a few fragments are seen and these species are labelled as tentative assignments in the table. The molecules identified range in molar mass from 116 to $288 \mathrm{Da}$ and have a different distribution depending on photochemical age and the initial concentration of the precursor, as will be discussed later in Sects. 3.3 and 3.4, respectively.

The largest ion abundances relate to compounds with molar masses of 252 and $254 \mathrm{Da}$. One large peak is seen in the negative ionisation LC extracted ion chromatogram of $m / z 251$ (see Supplement Fig. S2), which has been tentatively identified as $\beta$-caryophyllonic acid due to a loss of 18 $\left(\mathrm{H}_{2} \mathrm{O}\right)$ and $44\left(\mathrm{CO}_{2}\right)$ in negative ionisation (see Supplement Fig. S2) and 18 and $46\left(\mathrm{HCO}_{2} \mathrm{H}\right)$ in positive ionisation. However, recent results from Nørgaard et al. (2008), using collision induced dissociation of secondary ozonides (SOZ) from monoterpenes ozonolysis, resulted in fragmentation via loss of 18 or $44 \mathrm{Da}$. Therefore, without a standard, it is impossible to completely rule out a contribution from the SOZ, although its vapour pressure is estimated to be three orders of magnitude higher than that of $\beta$-caryophyllonic acid, consistent with it being primarily in the gas phase (Jenkin et al., 2012). There are 5 peaks (1 very large peak at $42 \mathrm{~min}$, 1 medium peak at $52 \mathrm{~min}$ and three very small peaks) in the negative ionisation LC extracted ion chromatogram of $m / z 253$ (see Supplement Fig. S1). The largest peak is at a retention time of $42 \mathrm{~min}$ and the $\mathrm{m} / \mathrm{z} 253$ ion gives major fragment ions at $m / z 235$ and 191 [losses of $18 \mathrm{Da}\left(\mathrm{H}_{2} \mathrm{O}\right)$ and $\left.62 \mathrm{Da}\left(\mathrm{H}_{2} \mathrm{O}+\mathrm{CO}_{2}\right)\right]$ and two small fragment ions at $\mathrm{m} / z 207$ and 209 [losses of $46 \mathrm{Da}\left(\mathrm{CH}_{3} \mathrm{COH}\right)$ and $44 \mathrm{Da}\left(\mathrm{CO}_{2}\right)$ ] (as shown in the upper panel of Supplement Fig. S3). In addition there is a minor fragment ion at $m / z 151 \mathrm{Da}$, corresponding to a loss of $102 \mathrm{Da}$. The loss of 102 may be a loss of $\mathrm{CHOCH}_{2} \mathrm{CH}_{2} \mathrm{COOH}$ and thus this peak has been assigned as $\beta$-nocaryophyllonic acid. The medium peak at a retention time of $52 \mathrm{~min}$ has large fragment ions at $\mathrm{m} / \mathrm{z} 209$ and 191, giving losses of $44\left(\mathrm{CO}_{2}\right)$ and $62\left(\mathrm{H}_{2} \mathrm{O}+\mathrm{CO}_{2}\right)$, respectively (as shown in the lower panel of Supplement Fig. S3). This peak has been assigned to $\beta$-caryophyllinic acid due to the high intensity $m / z 209$ peak. There are no other obvious ionisation locations on the $\beta$-caryophyllinic acid other than the acid groups, which may explain why the loss of $44 \mathrm{Da}$ is favoured for the diacid over the $\beta$-nocaryophyllonic acid, which can lose both $18 \mathrm{Da}$ (from one of the carbonyl groups) and $44 \mathrm{Da}$ (from the acid). Further work is needed to confirm this fragmentation pattern and structural assignment. In all cases the most abundant compounds are $\beta$-caryophyllonic acid/SOZ (252 Da) and $\beta$-caryophyllinic $\mathrm{acid} / \beta$-nocaryophyllonic acid $(254 \mathrm{Da})$, which are all products of $\beta$-caryophyllene ozonolysis as reported in the literature (Jaoui et al., 2003; Winterhalter et al., 2009). It should be noted that $\beta$-nocaryophyllonic acid is an isomer of $\beta$ caryophyllinic acid. Recently, Chan et al. (2011) were unable to distinguish these two compounds on the basis of accurate mass measurements alone, and were therefore not specific about attribution in their $\beta$-caryophyllene $/ \mathrm{NO}_{\mathrm{x}}$ photooxidation study. The added benefits of compound separation by liquid chromatography and identification using tandem MS in our employed techniques enabled us to confirm the presence of both compounds in SOA formed from photo-oxidation of $\beta$-caryophyllene/ $/ \mathrm{NO}_{\mathrm{x}}$ mixtures. From a gas-phase mechanistic point of view, there seems little doubt that the $\beta$-nocaryophyllonic acid will be formed as an important second-generation product as the system ages, as it is the likely major product of both of $\mathrm{O}_{3}$ and $\mathrm{OH}$ initiated oxidation of $\beta$-caryophyllonic acid (Jenkin et al., 2012). In addition to this, $\beta$-nocaryophyllonic acid can be formed from the likely very rapid ozonolysis of $\beta$ nocaryophyllone (a significant product of the $\mathrm{OH}$-initiated oxidation of $\beta$-caryophyllene), providing a relatively prompt source in the system. So it is predicted to be an important second generation product, and with a vapour pressure approaching an order of magnitude lower than that of $\beta$-caryophyllonic acid, should be an important SOA contributor (Jenkin et al., 2012). Jaoui et al. (2003) identified 3,3-dimethyl-2-(3-oxobutyl)-cyclobutane-methanal and 3,3-dimethyl-2-ethanal-cyclobutane, of molar mass 192 and $154 \mathrm{~g} \mathrm{~mol}^{-1}$, respectively in the condensed phase produced in dark ozonolysis experiments. Neither of those aldehyde compounds was detected in our photo-oxidation experiments, where oxo-, hydroxyl- and poly- carboxylic acids dominated the composition of the identified compounds. This may be a result of poor ionisation efficiency of carbonyl species using electrospray ionisation (Glasius et al., 2000).

$\mathrm{O}: \mathrm{C}$ and $\mathrm{H}: \mathrm{C}$ elemental ratios of the identified products range from 0.20 to 1.00 and 1.00 to 2.00 , with average values of 0.39 and 1.58 , respectively. The range of these values is a little wider than the corresponding range found by $\mathrm{Li}$ et al. (2011) for dark ozonolysis experiments, where they reported $\mathrm{O}: \mathrm{C}$ and $\mathrm{H}: \mathrm{C}$ elemental ratios of 0.13 to 0.50 and 1.43 to 1.60 , respectively. Figure 2 shows a 2-D representation of the relationship between $\mathrm{O}: \mathrm{C}$ ratio and saturation concentration (Donahue et al., 2006) for all of the identified molecules in Table 2 coloured by their molar mass. Mass based C(i)* values were calculated from the vapour pressure values using the method of Donahue et al. (2006) with the assumption of liquid phase ideality (all activity coefficients $=1$ ). To obtain the vapour pressure data the boiling point was first estimated using the method of Nannoolal et al. (2004), and then extrapolated to ambient temperatures using the vapour pressure equation of Nannoolal et al. (2008). Parameters for atmospherically important functional groups that are not covered by the original methods (e.g. hydroperoxide) were obtained from the literature (Compernolle et al., 2010). $\beta$-Caryophyllene is also included in this figure to indicate the origin of these molecules. The data shows the expected trend of an increase of the $\mathrm{O}: \mathrm{C}$ ratio associated with a decrease in the saturation concentration for the 
Table 2. Suggested structures, molar masses, retention times and elemental ratios of $\beta$-caryophyllene SOA compounds identified by LCMS/MS. The ratio of LC peak area for compounds identified in SOA collected at $6 \mathrm{~h}$ in a higher concentration experiment (16/04/08) and lower concentration experiment (24/04/08) is also given.

\begin{tabular}{|c|c|c|c|c|c|c|c|}
\hline Compound & Structure & $\begin{array}{r}\text { Molar } \\
\text { Mass }\end{array}$ & {$[\mathrm{M}-\mathrm{H}]^{-}$} & $\begin{array}{r}\mathrm{RT} \\
(\mathrm{min})\end{array}$ & $\mathrm{O}: \mathrm{C}$ & $\mathrm{H}: \mathrm{C}$ & $\begin{array}{r}\text { Ratio } \\
\text { "higher"/“lower" }\end{array}$ \\
\hline 3,4-dioxobutanoic acid & & 116 & 115 & 11.5 & 1.0 & 1.0 & 0.80 \\
\hline 3-hydroxy-4-oxobutanoic acid & & 118 & 117 & 12.9 & 1.0 & 1.50 & 0.82 \\
\hline nor-caryophyllenic acid & & 172 & 171 & 20.7 & 0.5 & 1.50 & 1.11 \\
\hline $\begin{array}{l}\text { 2-(2-hydroxy-ethyl)-3,3-dimethyl } \\
\text {-cyclobutanecarboxylic acid }\end{array}$ & & 172 & 171 & 44 & 0.33 & 1.78 & 3.56 \\
\hline $\begin{array}{l}\text { 3,3-dimethyl-2-(3-oxo-propyl)- } \\
\text { cyclobutanecarboxylic acid }\end{array}$ & & 184 & 183 & 51.6 & 0.3 & 1.60 & 1.91 \\
\hline $\begin{array}{l}\text { 3-(2-hydroxy-3,3- } \\
\text { dimethylcyclobutyl)- } \\
\text { but-3-enoic acid }\end{array}$ & & 184 & 183 & 43.8 & 0.3 & 1.60 & 4.27 \\
\hline $\begin{array}{l}\text { 2-(carboxymethyl)-3,3- } \\
\text { dimethylcyclobutanecarboxylic acid }\end{array}$ & & 186 & 185 & 20.7 & 0.44 & 1.56 & 1.25 \\
\hline $\begin{array}{l}\text { 3,3-dimethyl-2-(3- } \\
\text { oxobutyl)cyclobutanecarboxylic acid }\end{array}$ & & 198 & 197 & 47 & 0.27 & 1.64 & 1.62 \\
\hline
\end{tabular}


Table 2. Continued.

\begin{tabular}{|c|c|c|c|c|c|c|c|}
\hline Compound & Structure & $\begin{array}{r}\text { Molar } \\
\text { Mass }\end{array}$ & {$[\mathrm{M}-\mathrm{H}]^{-}$} & $\begin{array}{r}\mathrm{RT} \\
(\min )\end{array}$ & $\mathrm{O}: \mathrm{C}$ & $\mathrm{H}: \mathrm{C}$ & $\begin{array}{r}\text { Ratio } \\
\text { "higher"/“lower" }\end{array}$ \\
\hline $\begin{array}{l}\text { 2-(2-carboxyethyl)-3,3- } \\
\text { dimethylcyclobutanecarboxylic acid }\end{array}$ & ${ }_{0}^{\|}$ & 200 & 199 & 30.8 & 0.4 & 1.60 & 0.91 \\
\hline
\end{tabular}

2-(2-(2-carboxyethyl)-3,3-

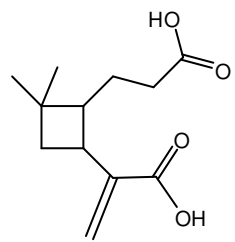

dimethylcyclobutyl)acrylic acid

\begin{tabular}{l}
$\begin{array}{l}\text { 3-[2,2-dimethyl-4-(1- } \\
\text { methylene-4-oxo-butyl)- } \\
\text { cyclobutyl]-propionic acid }\end{array}$ \\
\hline
\end{tabular}

3-hydroxy-3-[4-(3-hydroxy-1-<smiles>C=C(CCO)C1CC(C)(C)C1C(O)CC(=O)O</smiles>

methylene-propyl)-2,2-

dimethylcyclobutyl]-

propionic acid

$\beta$ - caryophyllonic acid ${ }^{\mathrm{a}}$


Table 2. Continued.

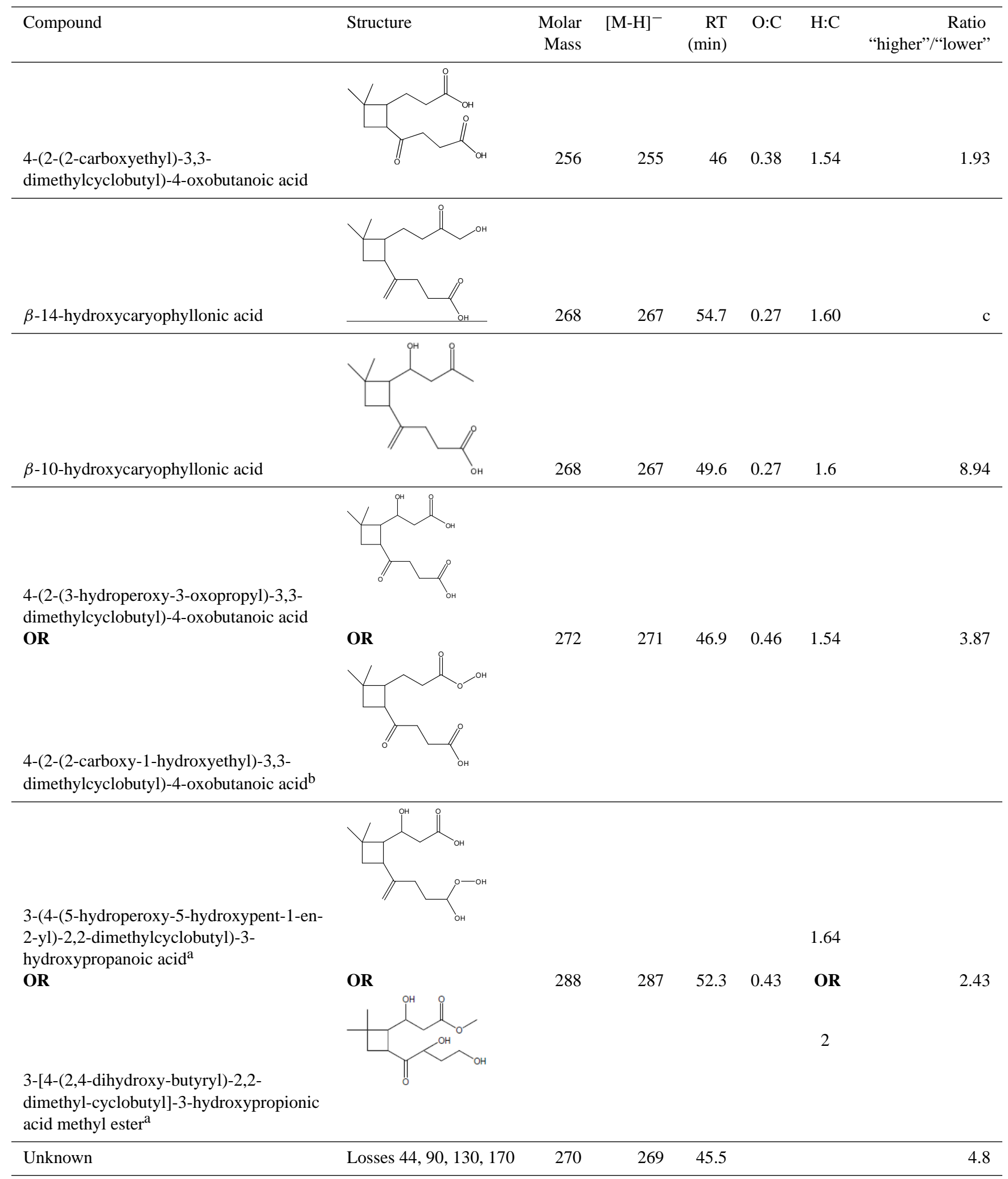

${ }^{a}$ Tentative assignment; ${ }^{b}$ Fragmentation insufficient for structural identification; ${ }^{c}$ Not present in one sample. 


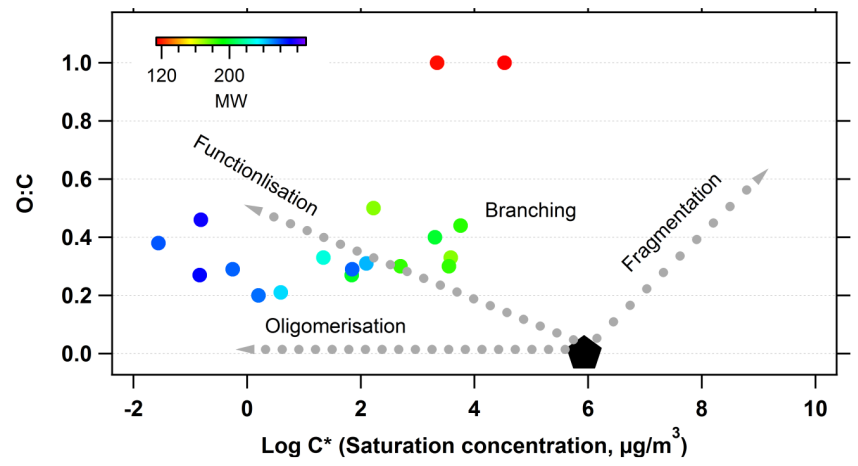

Fig. 2. A 2-D representation of the relationship between $\mathrm{O}: \mathrm{C}$ ratio and saturation concentration for all of the identified molecules in Table 2 coloured by their molar masses.

vast majority of the identified compounds in Table 2, confirming that photo-oxidation leads to functionalised products with an increasing $\mathrm{O}: \mathrm{C}$ ratio. The two compounds with molar masses of 116 and $118 \mathrm{Da}$ and $\mathrm{O}: \mathrm{C}$ ratios of 1 are likely to be higher generation products from further oxidation and ageing, as will be discussed in Sect. 3.3.

\subsection{Ageing of $\beta$-caryophyllene SOA}

The extracts obtained from the filters were directly injected into the ion trap mass spectrometer without separation using a syringe pump at $240 \mu \mathrm{lpm}$, to obtain a molar mass distribution. This allows a quick visual comparison to be made between SOA of different degrees of ageing. Figure 3 shows the negative ion $m / z$ distribution of the lower and higher initial concentration samples at $2 \mathrm{~h}$ and $6 \mathrm{~h}$. Prior to the experiments presented here, $2 \alpha$-pinene experiments were carried out under identical conditions ( $30 \mathrm{ppbV} \mathrm{VOC)} \mathrm{but} \mathrm{on}$ consecutive days to test variability. Filter samples were collected at the same point in each experiment and the samples were analysed using LC-MS. Eight $\alpha$-pinene SOA peaks were chosen (including cis-pinonic acid and 3-methyl-1,2,3butanetricarboxylic acid - MBTCA) and the peak areas were determined. The ratio of peak areas between the two samples was calculated and gave an average value of 1.17. This indicates that any variability seen in the mass spectra for the $\beta$-caryophyllene analysis is a result of aerosol ageing and not a product of experiments being conducted on different days.

It is clear from Fig. 3 that photochemical ageing changes the SOA composition. After two hours of ageing the SOA composition is relatively simple and is dominated by peaks from $m / z, 230-340$. As the photochemical ageing proceeds, the condensed phase mass spectra become increasingly complex. This can be seen over the range $m / z$ 200-290, where rather than comprising single peaks $14-16 \mathrm{~m} / \mathrm{z}$ apart, as was seen at $t=2 \mathrm{~h}$, the mass spectra at $t=6 \mathrm{~h}$ starts to fill up at every odd mass. There is also a change in the molar mass distribution with time, with an increase in smaller molecules as the SOA ages. This can clearly be seen by subtracting the mass spectra of the early SOA $(2 \mathrm{~h})$ from the aged SOA $(6 h)$ as shown in Fig. 4. In this figure, the mass spectra have been scaled according to the amount of SOA on the filter. Peaks that point downwards indicate ions that have higher relative contribution to the mass after $2 \mathrm{~h}$ (i.e. less aged SOA) and peaks that point upwards indicate ions that contribute more to the mass after $6 \mathrm{~h}$ of ageing (i.e. more aged SOA). It is clear that the highest molar mass compounds dominate after $2 \mathrm{~h}$, whereas after $6 \mathrm{~h}$ of ageing there is a greater number of lower molar mass species where both double bonds have been oxidised.

The bulk composition of the SOA formed was also measured in real-time using a cTOF-AMS. These measurements were not suitable for molecular identification owing to the lack of ion separation and the nature of the electron impact ionisation technique. However, they can provide highly time resolved information on the chemical composition using overall mass spectral patterns and changes in key mass fragments. For example, mass fragments $m / z 43$ and 44 can broadly be used to indicate the presence of "less" and "more" oxidised SOA respectively (Alfarra et al., 2006; Lanz et al., 2007; Jimenez et al., 2009; Alfarra et al., 2004). During the current experiments, it was observed that $\mathrm{m} / z 43$ dominated the cTOF-AMS mass spectra along with a relatively low contribution of $m / z 44$, contributing $13-16 \%$ and $<5 \%$ to the total SOA signal, respectively. The fractional contributions of the 43 and 44 fragments to the total mass spectra ( $f 43$ and $f 44$ ) at each time point for multiple lower and higher initial concentration experiments are plotted in the bottom panel of Fig. 5. In the higher initial concentration experiments, ageing led to only a very small change in the $f 43$ and $f 44$, indicating very little change in the SOA composition as a function of photochemical ageing. However, this effect is significantly enhanced for experiments with lower initial precursor concentration, where the value of $f 44$ increases from around 3 to $5 \%$ over a period of $4 \mathrm{~h}$. Ageing is also seen in a reduction in the less oxidised fragment ( $f 43)$, which drops from 16 to $12 \%$ over the same period. The combined effect of photochemical ageing on the changes in both mass fragments is shown in the top panel of Fig. 5, which shows a plot of the ratio of $f 44 / f 43$ as a function of time. This illustrates that ageing has a significantly greater effect on the SOA composition and degree of oxidation when experiments are carried out at lower concentrations.

A 2-D representation of the transformation of the chemical composition of $\beta$-caryophyllene SOA in the context of previously published ambient data is presented in Fig. 6. The dotted lines show the relationship between $f 44$ and $f 43$ for a large number of ambient datasets collected at locations in the Northern Hemisphere and discussed in detail by $\mathrm{Ng}$ et al. (2010). The chamber generated $\beta$-caryophyllene SOA data are located in the bottom right corner of the ambient triangle, indicating that the aerosol is mostly composed of semi-volatile material. Similar to the discussion above, 


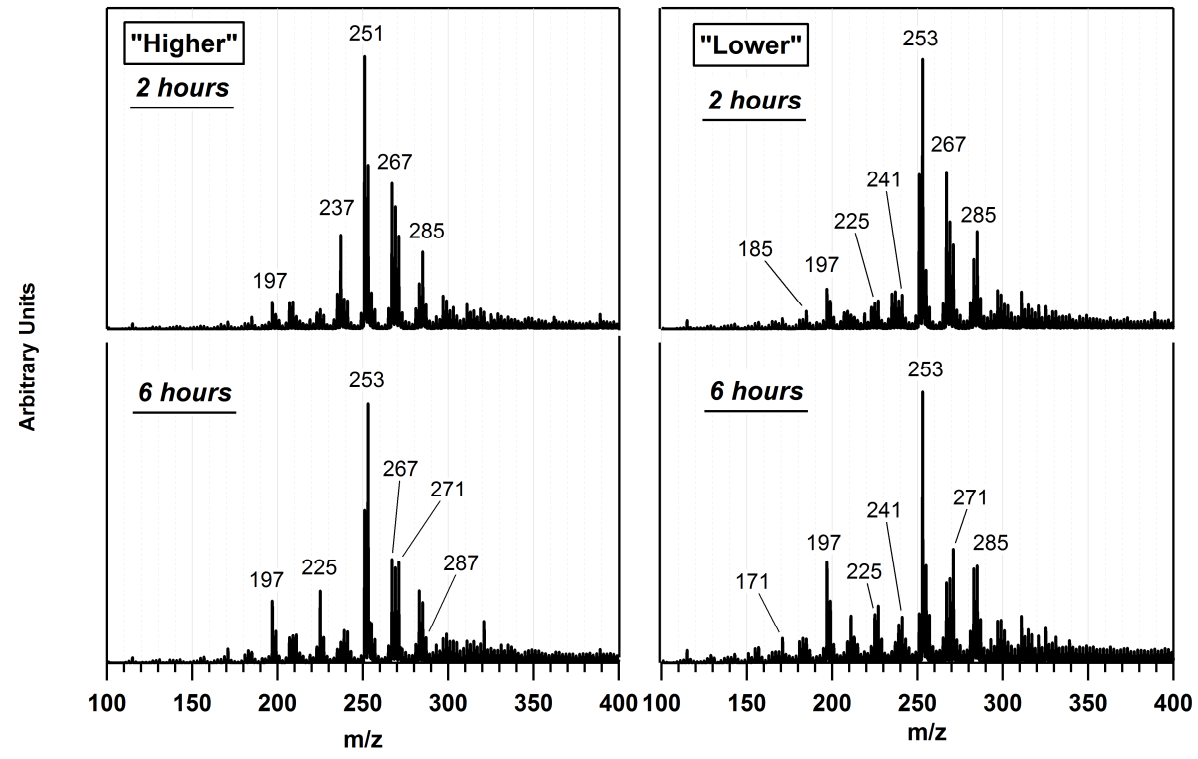

Fig. 3. Negative ion $m / z$ distributions $\beta$-caryophyllene SOA samples produced under higher and lower initial concentration conditions after 2 and $6 \mathrm{~h}$ of photo-oxidation. The suggested structures of the labelled peaks are listed in Table 2.

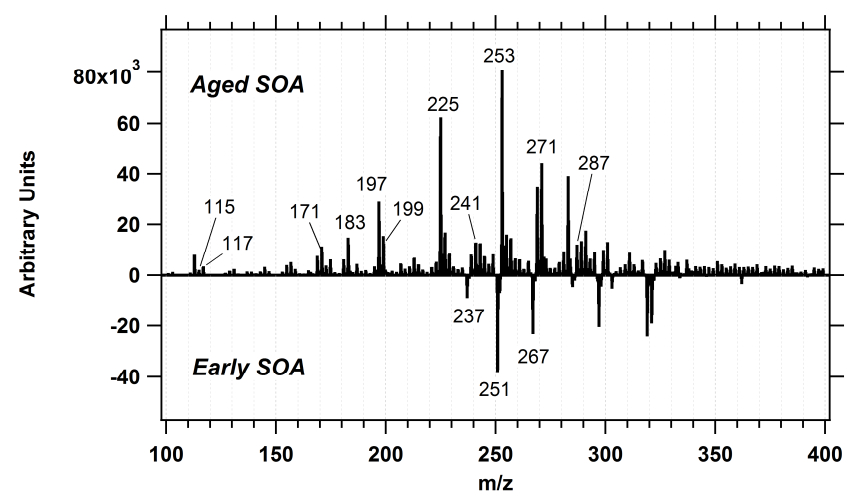

Fig. 4. The difference between a mass spectral distribution of an aged $\beta$-caryophyllene SOA sample (6h) and an early one ( $2 \mathrm{~h})$. The mass spectra have been scaled according to the amount of SOA collected in each case. Peaks that point downwards indicate ions that have higher relative contribution to the mass after $2 \mathrm{~h}$ (i.e. less aged SOA) and peaks that point upwards indicate ions that contribute more to the mass after $6 \mathrm{~h}$ of ageing (i.e. more aged SOA). The suggested structures of the labelled peaks are listed in Table 2.

ageing appears to transform the SOA formed in the lower initial concentration experiments towards more oxygenated material; in contrast, photochemical ageing has very little effect on the chemical characteristics of the SOA formed in the higher concentration experiments.

The same effect is seen in the speciated composition obtained from the filter extracts. The offline condensed phase mass spectra of both higher and lower concentration experiments at 2 and $6 \mathrm{~h}$ are shown in Fig. 3. Lower initial concentration experiments lead to a more complex and more

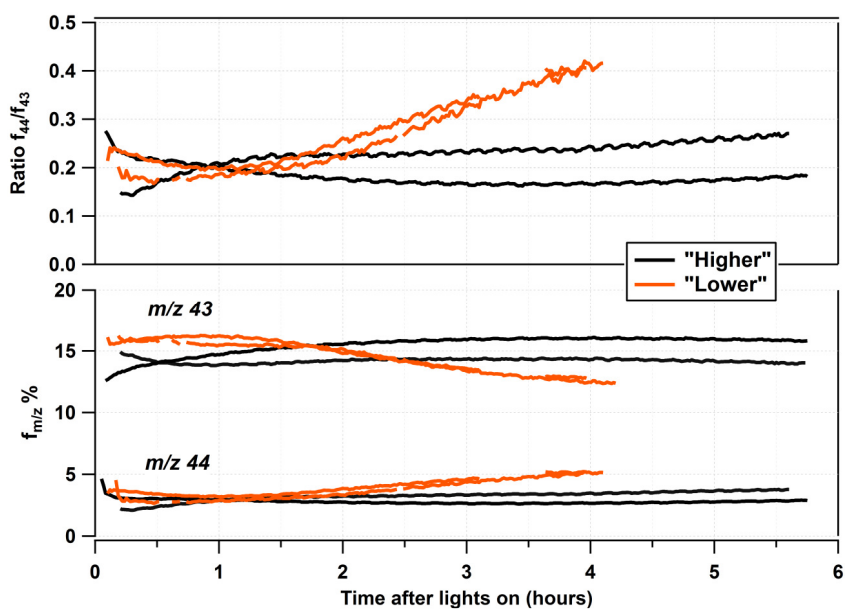

Fig. 5. Temporal trends of the fractional contribution of key mass fragments $(m / z 43$ and 44$)$ to the total SOA signal as measured by the cTOF-AMS during a number of experiments using higher and lower initial precursor concentrations (bottom panel). The top panel shows the ratio of $f 44 / f 43$ as a function of time; illustrating that ageing has a significantly greater effect on the SOA degree of oxidation when experiments are carried out at lower precursor concentrations.

oxidised SOA than that which was formed by the same time in the higher initial concentration experiments. This result supports the hypothesis that experiments starting with lower precursor concentrations require multiple generations of oxidation to produce sufficient amounts of low vapour pressure products. A more detailed discussion of the effect of the initial VOC concentration on the speciated chemical 


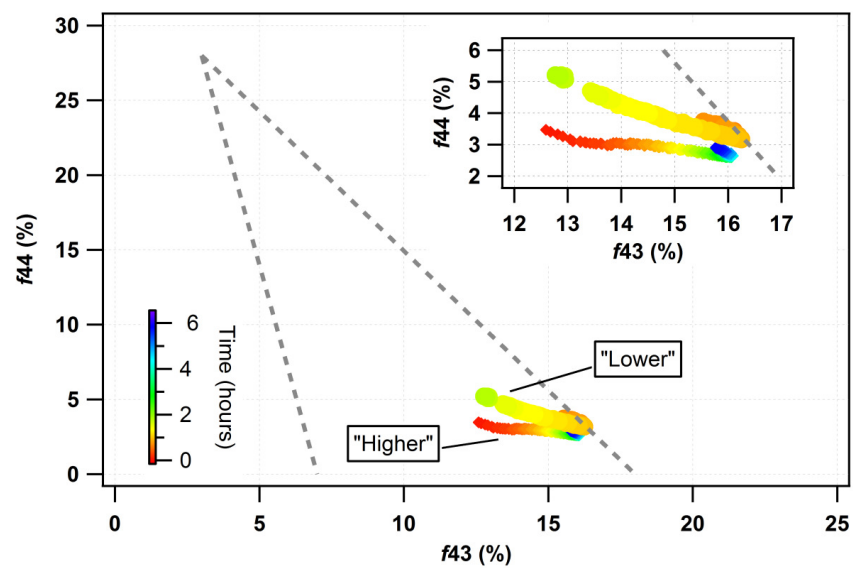

Fig. 6. The relationship between $f 44$ and $f 43$ for $\beta$-caryophyllene $\mathrm{SOA}$ in the context of previously published ambient datasets by $\mathrm{Ng}$ et al. (2010). The data points are coloured by time after the start of photo-oxidation. The insert in the top right corner shows a magnified view of the data points for clarity.

composition of the SOA formed is presented in the following section.

\subsection{Effect of initial precursor concentration on SOA composition}

The effect of the initial precursor concentration on SOA composition has been investigated by comparing the peak areas of liquid chromatography (LC) separated SOA components from one higher and one lower initial concentration experiments. The high : low ratios of SOA collected on the filter and peak SOA concentration in the chamber were 3.0 and 3.4 , respectively. Thus compounds that have ratios of the order of approximately $3.2 \pm 1.2$ (i.e. in the range 2.0-4.4) have roughly comparable contributions in the SOA generated from lower and higher precursor concentration experiments; compounds with a lower ratio are relatively more prominent in the low concentration experiment and those with a higher ratio are relatively more important in the higher concentration experiment. Table 3 lists the structures of some of the identified compounds in each category.

A close inspection of the compound structures presented in Table 3 shows that in the lower concentration experiments, the compounds comprising the SOA were more oxidised than those that were found to be more abundant in the higher initial concentration experiments. In general, those found to be more prominent in the lower initial concentration experiment had smaller carbon structures, with between only 4 and 13 carbon atoms and an average $\mathrm{O}: \mathrm{C}$ ratio of 0.51. Furthermore, these "lower" molar mass molecules were found to primarily comprise low volatility dicarboxylic acids, with a few species containing an alcohol, aldehyde or ketone functional group as well as an acid moiety. The species found in approximately equal quantities in both types of SOA had larger $\mathrm{C}_{9}-\mathrm{C}_{14}$ carbon structures and an average $\mathrm{O}: \mathrm{C}$ ratio of 0.34 . They contained multiple different types of functional groups, although two of the species present also comprised dicarboxylic acids. Those species found predominantly in the higher initial concentration experiments had the largest carbon structures, with between 12 and 15 carbon atoms per compound with an average $\mathrm{O}: \mathrm{C}$ ratio of 0.27 and possessed an unsaturated carbon bond and 2-3 functional groups, the most common, again, being an acid moiety. In order to be consistent with absorptive partitioning, such that lower condensed mass comprises lower volatility components, it is clear that the reduced volatility by virtue of the increased $\mathrm{O}: \mathrm{C}$ ratio at lower concentrations more than offsets increased volatility by virtue of the corresponding reduction of molar mass.

\subsection{Hygroscopic properties of $\beta$-caryophyllene SOA}

The hygroscopic growth at $90 \% \mathrm{RH}$ was measured by the HTDMA for particles generated during the experiments listed in Tables 1a and b. Dry particle diameters were set between 50 and $300 \mathrm{~nm}$, with the larger diameters set later in the experiments as the diameter of the mode of the number size distribution increased. At each selected diameter the HTDMA resolved a narrow mono-modal growth factor probability density distribution (GFPDF), this shows that there is little or no difference between the growth factors of individual particles at a measured dry size. Hence the mean of the GFPDF represents well (that is, with a small deviation from the mean) the measured particle hygroscopic growth reported in this study. Similarly the HTDMA was unable to resolve any significant differences in the GFPDF as a function of selected dry diameter at any single time, this shows that there is no significant difference in hygroscopicity between the different sized particles measured and is consistent with the fact that the curvature of the particle surface will not have a significant impact at the selected diameters. It should be noted that it is only possible to select from a relatively narrow range of particle sizes at any one-time; firstly, because particles with diameters smaller than the modal diameter cannot be selected without simultaneously sampling comparable numbers of multi-charged larger particles of equal electrical mobility and secondly due to the intrinsically narrow number size distribution produced in the chamber. Thus it is not possible to disentangle any differences in water uptake as a function of their size. The experiment-to-experiment variability was as large as the in-experiment temporal and size dependent variability, but was within a small enough range that it generally fell within the experimental uncertainty of the other experiments. The growth factors measured during the lower and higher concentration experiments were consistently within experimental uncertainty of each other.

Figure 7 illustrates the mean hygroscopic growth factors measured by the HTDMA at $90 \%$ RH. It includes data from 7 separate experiments, 3 with lower initial concentration and 
Table 3. List of compounds identified in Table 2, which were found to be more abundant under "lower" initial precursor concentration (ratio less than 2.0), "higher" initial precursor concentration (ratio greater than 4.4), and around equal under both initial conditions (ratio 2.0-4.4). See text for further discussion. The ratios of LC peak areas are listed in Table 2.

Ratio less than 2.0

4 with higher initial concentration of the $\beta$-caryophyllene precursor. The mean growth factors ranged from 1.00 to 1.09 , with a 10th to 90th percentile range of 1.00 to 1.06 ; equivalent to $\kappa$-values (Petters and Kreidenweis, 2008) between 0 and 0.03 for the particle diameters selected (between 50$300 \mathrm{~nm}$ ). There was no repeatable difference in the measured growth factors between experiments using different initial concentrations. The error bars in Fig. 7 are calculated based on the instrument having an inherent uncertainty of \pm 0.02 in growth factor due to repeatability of the tandem DMA sizing and a $\pm 1.5 \%$ uncertainty in the RH measurement in the humidified DMA translated into a growth factor uncertainty using the $\kappa$ parameterisation (Petters and Kreidenweis, 2008; Gysel et al., 2009). As the measured growth factors are low the repeatability of the tandem DMA sizing is calculated to be the dominant contributor to the error. A limited number of $\mathrm{CCN}$ measurements were performed during the experiments reported in Table 1a, where the derived $\kappa$-values were also found to be similarly low to those reported by the HTDMA $\left(\kappa_{\mathrm{CCN}}-\right.$ values between 0 and 0.02 ).
Hygroscopic growth factors of particles formed from the photo-oxidation of $\beta$-caryophyllene ( $40 \mathrm{ppbV}$ at $50 \% \mathrm{RH}$ in the presence of $\mathrm{NO}_{\mathrm{x}}$ ) have been measured previously by Varutbangkul et al. (2006) and were 1.04 at $85 \%$ RH (equivalent to a $\kappa$-value of 0.024 for the $180 \mathrm{~nm}$ and $300 \mathrm{~nm}$ particles selected). The particles sampled by Varutbangkul et al. (2006) exhibited lower growth factors as a function of time, which was attributed to oligomerisation resulting in higher molar mass less polar species in the particles sampled. Varutbangkul et al. (2006) did not observe any selected dry size dependence in the growth factor.

In our study the mean growth factor of a given dry size tends to increase as the experiment progresses, though these trends are generally within measurement uncertainty and cannot be tracked throughout an experiment due to the increasing modal diameter of the number size distributions. This result contrasts with the aforementioned Varutbangul et al. (2006) study that observed a clear temporal decrease in the growth factor. Whilst oligomerisation is expected to decrease the growth factor with time, the increasingly oxidised nature of the particle composition (as measured in this study 


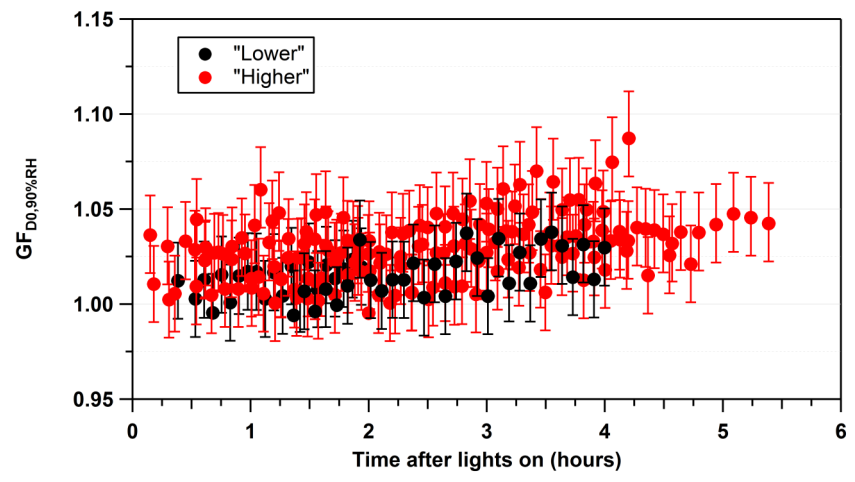

Fig. 7. The mean hygroscopic growth factors at $90 \% \mathrm{RH}$ as a function of photo-oxidation for $\beta$-caryophyllene SOA particles with selected dry diameters between $50-300 \mathrm{~nm}$ generated using lower and higher initial precursor concentrations.

by both online and offline methods) is expected to increase the particle hygroscopicity. In our study oligomers were not observed in the composition measurements (as found in the off-line mass spectral analysis), which is one possible reason a temporal decrease in the growth factor was not observed. Given the observed temporal growth factor trend, it can be concluded that the increasingly oxidised nature of the aerosol only has a minor positive effect on it, or that it is offset by other factors.

If a fraction of the aerosol formed were semi-volatile in the range of the experimental conditions it could have a significant impact on the measured growth factors. Asa-Awuku et al. (2009) reported that the hygroscopic fraction of the aerosol produced from the ozonolysis of $\beta$-caryophyllene is semi-volatile. By sampling the aerosol through a thermodenuder at $35^{\circ} \mathrm{C}$ and directly at $20^{\circ} \mathrm{C}$, Asa-Awuku et al. (2009) measured a reduction in the particle hygroscopicity of the denuded sample based on the difference in its size-resolved CCN activation. From these measurements and additional analysis (detailed in the manuscript) the authors concluded that the particles comprise a small fraction of semi-volatile relatively hygroscopic material. This semivolatile fraction would therefore account for a large fraction of the particle water content in a sub-saturated environment. This finding has implications related to the aerosol sampling and measurement techniques employed in such studies and makes comparing results with other studies performed under different conditions more difficult. Asa-Awuku et al. (2009) show that a fairly small change in the aerosol temperature (i.e. of the order of $10^{\circ} \mathrm{C}$ ) could change the particle hygroscopicity and if such changes occur within the instrumentation introduce artifacts. Drying the aerosol, a requirement for mobility size selecting particles in the HTDMA and size resolved CCN measurements could also alter the particle composition and change its hygroscopic properties (Topping et al., 2011). If the aerosol produced in the current study is semi-volatile then it could affect the measured hygroscop- icity. If for example, the relatively hygroscopic components of the aerosol are in the gas phase when sampled through the HTDMA then the growth factor will be low and there may not be a response in the growth factor to an increase in the fraction of more hygroscopic species later in the experiment. Hence this is a possible explanation for the low observed growth factor and small response to the ageing of the aerosol.

In summary, the measured growth factors show there is little water uptake at $90 \% \mathrm{RH}$. Any size, temporal or precursor dependent change in the hygroscopicity is generally within the measurement uncertainty and not repeatedly different. The increasingly oxidised nature of the aerosol appears to increase the growth factor only marginally, if at all. The species that make up the particles appear to have a low hygroscopicity.

\subsection{Gas phase composition and linkages to the condensed phase}

The majority of peaks detected in the gas phase CIR-TOFMS spectra lay in the approximate range 70-255 Da (with ions detected with $\mathrm{m} / \mathrm{z}$ ratio as high as $271 \mathrm{Da}$ ). The relatively high mass ions $m / z$ 253, 237, 235, 221, 209, 207, 203, 191 and 165 were typically the greatest contributors to the gas phase mass spectra during each experiment. The majority of the total ion signal comprising the condensed phase LCMS spectra fell in the somewhat higher approximate range $\mathrm{m} / z$ 200-350 (with ions detected with $\mathrm{m} / \mathrm{z}$ ratio as low as $115 \mathrm{Da}$ ). As such, a window of overlap of the order $50 \mathrm{Da}$ existed between the mass spectra of the two phases. In this overlap window there were a number of concomitant mass peaks that potentially represent compounds that were present in both the gas and the condensed phases; these included compounds of molar masses 200 (199/201), 238 (237/239), 252 (251/253), 254 (253/255), 268 (267/269) and 288 (287/289) (each mass corrected for ionisation method and in the case of the latter, potential parent ion dehydration in the CIR-TOFMS. See Table 2 for further information).

Perhaps the two most significant features of overlap between the two sets of mass spectra involve the ions of $m / z 251$ and 253 from the condensed phase and the ions of $\mathrm{m} / z 253$ and 255 from the gas phase, potentially representing compounds of molar masses 252 and 254. In the condensed phase, the ions of $\mathrm{m} / z 251$ and 253 were observed to have some of the largest peaks in the mass spectrum at each stage of the experiment and were identified to be $\beta$-caryophyllonic acid and $\beta$-caryophyllinic acid $/ \beta$ nocaryophyllonic acid, respectively. In the gas phase, the spectral peak at $m / z 253$ was also amongst the largest spectral features detected throughout the experiment; however, the ion of $m / z 255$ was amongst the smallest signals observed (partly as a result of parent fragmentation following ionisation). Following the oxidation of $\beta$ caryophyllene, three different $\mathrm{C}_{15}$ primary products with a 


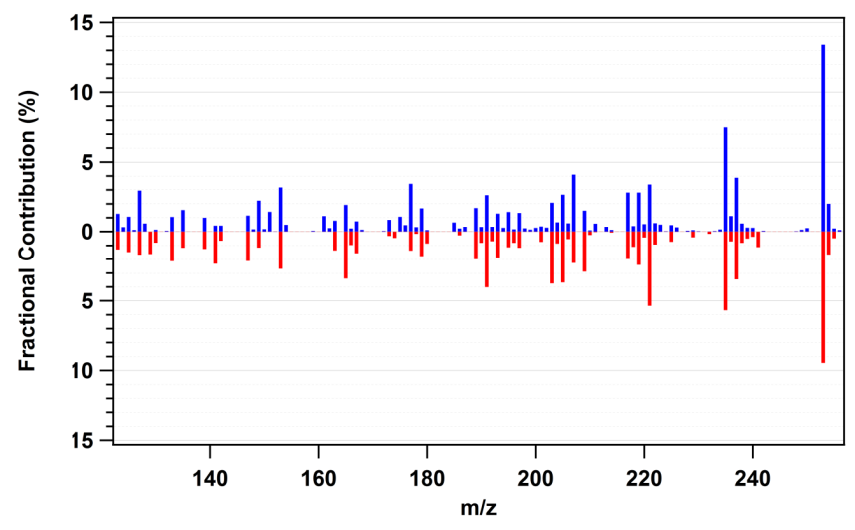

Fig. 8. A comparison of the gas phase mass spectra obtained from two $\beta$-caryophyllene photo-oxidation experiments; one higher initial concentration (upwards pointing bars) and one lower initial concentration experiment (downwards pointing bars) after $99 \%$ of the precursor had been consumed. Each peak represented as a fraction of the total organic ion count.

molar mass of 252 may be formed in the gas phase, including $\beta$-caryophyllonic acid and the $\beta$-caryophyllene secondary ozonide, and four different $\mathrm{C}_{14}$ products (one primary and three secondary) may be formed with a molar mass of 254 , including the primary product, $\beta$-caryophyllinic acid (although this is predicted to form with a very low yield in the presence of $\mathrm{NO}_{\mathrm{x}}$ by currently proposed gas-phase formation mechanisms) and $\beta$-nocaryophyllonic acid (Jenkin et al., 2012). The calculated vapour saturation concentrations (C(i)*) for the $\beta$-caryophyllonic, $\beta$-caryophyllinic and $\beta$-nocaryophyllonic acids are $70.5,0.55$ and $8.5 \mu \mathrm{g} \mathrm{m}^{-3}$, respectively. These values are consistent with the detection of $\beta$-caryophyllonic acid in both phases (gas and condensed) under the experimental aerosol mass loadings obtained here, whereas the majority of $\beta$-caryophyllinic and $\beta$-nocaryophyllonic acids were measured in the condensed phase, as may be expected from their lower volatility. Another significant contributor to the gas phase mass spectrum was the ion of $m / z 237$ (molar mass 236), tentatively assigned to be the primary product $\beta$-caryophyllon-aldehyde.

Such concomitancy between the two sets of measurements suggests a role for the direct partitioning of such major primary oxidation products from the gas to the condensed phase, facilitating nucleation and subsequent aerosol growth. However, the oxidation of certain primary species in the gas phase offers the potential for gas-aerosol partitioning of secondary products later during the experiment. A more indepth discussion regarding the identity of the gas phase ions observed and the speciated linkages between the gas and condensed phases of the $\beta$-caryophyllene oxidation system is presented in a separate publication, alongside a detailed mechanistic investigation (Jenkin et al., 2012).

\subsection{Ageing of the $\beta$-caryophyllene gas phase system and effect of initial precursor concentration}

Figure 8 shows a comparison of the gas phase mass spectra obtained from two typical $\beta$-caryophyllene photo-oxidation experiments; one higher initial concentration (21 November 2007, upwards pointing bars) and one lower initial concentration experiment (20 November 2007, downwards pointing bars), over the spectral range $123 \leq m / z \leq 255 \mathrm{Da}$. In order to demonstrate how the gaseous organic content of the system aged under each set of conditions, the spectra presented show the composition of the gas phase matrix after $99 \%$ of the precursor had been consumed.

From Fig. 8 it is clear that in terms of spectral composition, the two different gas phase systems aged in a somewhat similar way, with the mass spectra of each being generally composed of ions of the same $m / z$ ratio and with each being dominated by ions pertaining to the primary oxidation products of $\beta$-caryophyllene (e.g. $m / z 253,235$ ). It should be noted however, that although it is possible to state that the spectral composition did not alter significantly between the two scenarios, with the proton transfer reaction ionisation technique it is not always possible to distinguish between different structural isomers; such compounds often produce similar spectral fingerprints (Wyche et al., 2005). Therefore, it is not possible here to exclude the possibility that there was a change in abundance of species of the isobaric compounds that contribute to the same mass peak.

Although the general gas phase spectral composition of the two systems was similar as the matrix aged, from closer inspection of the data it becomes apparent that there were a number of minor differences in the absolute fractional make up of the spectra of each system. For instance, the higher initial concentration gas phase mass spectrum (Fig. 8, upwards pointing bars) was observed to contain a greater contribution from the peaks of $m / z 253,235,217$, 177 and 127 , which have been tentatively identified to belong to at least two isobaric primary products, i.e. the $\beta$ caryophyllene secondary ozonide and $\beta$-caryophyllonic acid (molar mass = 252) (Jenkin et al., 2012). At this stage of the higher concentration experiment these spectral features possessed a combined fractional abundance that was $\sim 1.5$ times greater than the equivalent peaks in the lower concentration spectra. Further to this, the $m / z 207$ peak, tentatively identified as primary oxidation product $\beta$-nocaryophyllone, was also found to be in greater fractional abundance under higher concentration conditions. These findings are in line with results presented earlier from the aerosol composition analysis, which showed that the higher concentration system produced a "fresher" aerosol containing a relatively greater contribution from certain less oxidised species, including $\beta$ caryophyllonic acid.

Conversely, the corresponding lower concentration gas phase mass spectrum (Fig. 8, downwards pointing bars) contained a slightly greater contribution from ions that are 
believed to result from a mixture of both primary and secondary generation compounds, including $m / z$ 209, 203, 193, 191,165 and 147, by factors in the range 1.5-1.9. None of these spectral features were found to be directly correlated with molecular ion peaks observed to be significantly more abundant in the mass spectra of the lower concentration aerosol (Table 3).

Consequently, with respect to the fractional contribution of ions to the mass spectra, the higher concentration gas phase matrix appeared slightly less aged than its lower concentration counterpart. Indeed, the gas phase composition would be expected to age more slowly under higher concentration conditions, as a greater proportion of first generation products would exist in the condensed phase and hence be protected from gas phase oxidation. The onward oxidation of the (relatively smaller) gas phase component would tend to draw material back out of the condensed phase so that net loss of relevant first generation products in the gas phase would be buffered. It follows therefore that the direct partitioning of a larger pool of such less aged material may have resulted in the observed fresher aerosol composition. With no significant evidence (within measureable limits) to directly link the compounds found in greater abundance in the lower concentration aerosol (left hand panel of Table 3) with ions in the lower concentration gas phase mass spectra, it is possible that condensed phase chemistry (i.e. aerosol ageing) may have had some role in their production. It should be noted however, that following mass branching through the system and considering potential re-volatilisation rates, such compounds may have been present in the gas phase below the detection limits of the instrumentation.

\section{Conclusions}

In this study, we characterised the chemical composition and hygroscopic properties of secondary organic aerosol (SOA) formed in the Manchester aerosol chamber during the photooxidation of $\beta$-caryophyllene/ $\mathrm{NO}_{\mathrm{x}}$ mixtures in the absence of pre-existing seed particles. The high reactivity of the sesquiterpene and the low volatility of its oxidation products led to a rapid nucleation and resulted in the formation of fresh SOA with a relatively simple chemical composition. $\beta$-caryophyllene SOA yield values ranged from $9.5-26.7 \%$ and 30.4-44.5\% using a DMPS and an AMS mass based measurements, respectively. The discrepancies between the DMPS and AMS mass measurements were possibly a result of the difference in pre-treatment of the semivolatilecontaining particles prior to the instrumentation.

A total of 20 compounds were identified in the SOA by LC-MS/MS, with the most abundant compounds identified as $\beta$-caryophyllonic acid (252 Da) and $\beta$-caryophyllinic acid/ $\beta$ nocaryophyllonic acid (254 Da). Unlike previous studies, we have been able to confirm the presence of the latter pair of isomers in SOA formed from photo-oxidation of $\beta$-caryophyllene $/ \mathrm{NO}_{\mathrm{x}}$ mixtures. $\beta$-caryophyllonic acid was detected in both of the gas and condensed phases; a finding consistent with its calculated vapour saturation concentration $\left(\mathrm{C}(\mathrm{i})^{*}\right)$ of $70.5 \mu \mathrm{g} \mathrm{m}{ }^{-3}$ under the experimental aerosol mass loadings obtained in the reported experiments. On the other hand, the majority of $\beta$-caryophyllinic and $\beta$-nocaryophyllonic acids were measured in the condensed phase, as predicted from their lower calculated vapour saturation concentrations of 0.55 and $8.5 \mu \mathrm{g} \mathrm{m}^{-3}$, respectively. The $\mathrm{O}: \mathrm{C}$ and $\mathrm{H}: \mathrm{C}$ elemental ratios of products identified in the condensed phase ranged from 0.20 to 1.00 and 1.00 to 2.00 , with average values of 0.39 and 1.58 , respectively. Our results showed that the increase in the $\mathrm{O}: \mathrm{C}$ ratio was associated with a decrease in the saturation concentration $\mathrm{C}(\mathrm{i})^{*}$ of the identified compounds, confirming that photo-oxidation leads to functionalised products with an increasing $\mathrm{O}: \mathrm{C}$ ratio.

The initial $\beta$-caryophyllene mixing ratios were varied between relatively low and relatively high levels to investigate the effect of initial precursor concentration on composition. We found that in the lower concentration experiments, the compounds comprising the SOA were more oxidised than those that were found to be more abundant in the higher initial concentration experiments. The former compounds had smaller carbon structures, with between only 4 and 13 carbon atoms and an average $\mathrm{O}: \mathrm{C}$ ratio of 0.51 . On the other hand, the latter compounds had the largest carbon structures, with between 12 and 15 carbon atoms per compound with an average $\mathrm{O}: \mathrm{C}$ ratio of 0.27 . These $\mathrm{O}: \mathrm{C}$ ratios were in line with findings in the gas phase, which showed that the higher concentration gas phase matrix appeared slightly less aged than its lower concentration counterpart. The effect of photochemical ageing on the speciated composition of the formed SOA was enabled by rapidly sampling the entire contents of the Manchester Aerosol Chamber onto filters 2 and $6 \mathrm{~h}$ after the start of repeat experiments. Ageing led to a more complex SOA composition with a larger contribution coming from lower molar mass, higher generation products, where both double bonds had been oxidised. This effect was more evident in the experiments conducted using the lower initial precursor concentration; a finding confirmed by the temporal behaviour of key organic mass fragment $(\mathrm{m} / z, 43$ and $m / z 44)$ measured by the AMS.

The hygroscopic growth of dry $\beta$-caryophyllene SOA particles with diameters between 50 and $300 \mathrm{~nm}$ was measured by an HTDMA at $90 \% \mathrm{RH}$. The mean growth factors ranged from 1.00 to 1.09 , with a 10th to 90th percentile range of 1.00 to 1.06 (equivalent to $\kappa$-value between 0 and 0.03 ). A limited number of $\mathrm{CCN}$ measurements resulted in a similarly low derived $\kappa$-values between 0 and 0.02. The HTDMA was unable to resolve any significant differences in the growth factors as a function of selected dry diameter at any single time, nor during the lower and higher concentration experiments. The increasingly oxidised nature of the aerosol appeared to increase the growth factor only marginally, if at all. 
These findings might have been influenced by the difference in pre-treatment of the semivolatile-containing particles prior to their measurements. More quantitative research is required to improve our understanding of influence of semi-volatile material on the properties of atmospheric aerosols.

\section{Supplementary material related to this article is available online at: http://www.atmos-chem-phys.net/12/ 6417/2012/acp-12-6417-2012-supplement.pdf.}

Acknowledgements. The authors gratefully acknowledge the UK Natural Environment Research Council (NERC) for funding of the APPRAISE ACES consortium (NE/E011217/1).

Edited by: R. MacKenzie

\section{References}

Alfarra, M. R., Coe, H., Allan, J. D., Bower, K. N., Boudries, H., Canagaratna, M. R., Jimenez, J. L., Jayne, J. T., Garforth, A., Li, S.-M., and Worsnop, D. R.: Characterization of urban and rural organic particulate in the Lower Fraser Valley using two Aerodyne aerosol mass spectrometers, Atmos. Environ., 38, 57455758, 2004.

Alfarra, M. R., Paulsen, D., Gysel, M., Garforth, A. A., Dommen, J., Prévôt, A. S. H., Worsnop, D. R., Baltensperger, U., and Coe, H.: A mass spectrometric study of secondary organic aerosols formed from the photooxidation of anthropogenic and biogenic precursors in a reaction chamber, Atmos. Chem. Phys., 6, 52795293, doi:10.5194/acp-6-5279-2006, 2006.

Arey, J., Winer, A. M., Atkinson, R., Aschmann, S. M., Long, W. D., Morrison, C. L., and Olszyk, D. M.: Terpenes emitted from agricultural species found in California's Central Valley, J. Geophys. Res., 96, 9329-9336, 1991.

Arey, J., Crowley, D. E., Crowley, M., Resketo, M., and Lester, J.: Hydrocarbon emissions from natural vegetation in California's South Coast Air Basin, Atmos. Environ., 29, 2977-2988, 1995.

Asa-Awuku, A., Engelhart, G. J., Lee, B. H., Pandis, S. N., and Nenes, A.: Relating CCN activity, volatility, and droplet growth kinetics of $\beta$-caryophyllene secondary organic aerosol, Atmos. Chem. Phys., 9, 795-812, doi:10.5194/acp-9-795-2009, 2009.

Atkinson, R. and Arey, J.: Gas-phase tropospheric chemistry of biogenic volatile organic compounds: a review, Atmos. Environ., 37, 197-219, 2003.

Bahreini, R., Keywood, M. D., Ng, N. L., Varutbangkul, V., Gao, S., Flagan, R. C., Seinfeld, J. H., Worsnop, D. R., and Jimenez, J. L.: Measurements of secondary organic aerosol from oxidation of cycloalkenes, terpenes, and $m$-xylene using an Aerodyne aerosol mass spectrometer, Environ. Sci. Technol., 39, 5674-5688, 2005.

Canagaratna, M. R., Jayne, J. T., Jimenez, J. L., Allan, J. D., Alfarra, M. R., Zhang, Q., Onasch, T. B., Drewnick, F., Coe, H., Middlebrook, A., Delia, A., Williams, L. R., Trimborn, A. M., Northway, M. J., DeCarlo, P. F., Kolb, C. E., Davidovits, P., and Worsnop, D. R.: Chemical and microphysical characterization of ambient aerosols with the aerodyne aerosol mass spectrometer, Mass Spectrom. Rev., 26, 185-222, 2007.
Chan, M. N., Surratt, J. D., Chan, A. W. H., Schilling, K., Offenberg, J. H., Lewandowski, M., Edney, E. O., Kleindienst, T. E., Jaoui, M., Edgerton, E. S., Tanner, R. L., Shaw, S. L., Zheng, M., Knipping, E. M., and Seinfeld, J. H.: Influence of aerosol acidity on the chemical composition of secondary organic aerosol from $\beta$-caryophyllene, Atmos. Chem. Phys., 11, 1735-1751, doi:10.5194/acp-11-1735-2011, 2011.

Compernolle, S., Ceulemans, K., and Müller, J.-F.: Technical Note: Vapor pressure estimation methods applied to secondary organic aerosol constituents from $\alpha$-pinene oxidation: an intercomparison study, Atmos. Chem. Phys., 10, 6271-6282, doi:10.5194/acp-10-6271-2010, 2010.

Cubison, M. J., Alfarra, M. R., Allan, J., Bower, K. N., Coe, H., McFiggans, G. B., Whitehead, J. D., Williams, P. I., Zhang, Q., Jimenez, J. L., Hopkins, J., and Lee, J.: The characterisation of pollution aerosol in a changing photochemical environment, Atmos. Chem. Phys., 6, 5573-5588, doi:10.5194/acp-6-5573-2006, 2006.

Donahue, N. M., Robinson, A. L., Stanier, C. O., and Pandis, S. N.: Coupled partitioning, dilution, and chemical aging of semivolatile organics, Environ. Sci. Technol., 40, 2635-2643, 2006.

Drewnick, F., Hings, S. S., DeCarlo, P., Jayne, J. T., Gonin, M., Fuhrer, K., Weimer, S., Jimenez, J. L., Demerjian, K. L., Borrmann, S., and Worsnop, D. R.: A new time-of-flight aerosol mass spectrometer (TOF-AMS) - Instrument description and first field deployment, Aerosol Sci. Technol., 39, 637-658, 2005.

Glasius, M., Lahaniati, M., Calogirou, A., Di Bella, D., Jensen, N. R., Hjorth, J., Kotzias, D., and Larsen, B. R.: Carboxylic Acids in Secondary Aerosols from Oxidation of Cyclic Monoterpenes by Ozone, Environ. Sci. Technol., 34, 1001-1010, 2000.

Goldstein, A. H. and Galbally, I. E.: Known and unexplored organic constituents in the earth's atmosphere, Environ. Sci. Technol., 41, 1514-1521, 2007.

Good, N., Coe, H., and McFiggans, G.: Instrumentational operation and analytical methodology for the reconciliation of aerosol water uptake under sub- and supersaturated conditions, Atmos. Meas. Tech., 3, 1241-1254, doi:10.5194/amt-3-1241-2010, 2010a.

Good, N., Topping, D. O., Duplissy, J., Gysel, M., Meyer, N. K., Metzger, A., Turner, S. F., Baltensperger, U., Ristovski, Z., Weingartner, E., Coe, H., and McFiggans, G.: Widening the gap between measurement and modelling of secondary organic aerosol properties?, Atmos. Chem. Phys., 10, 2577-2593, doi:10.5194/acp-10-2577-2010, 2010b.

Griffin, R. J., Cocker III, D. R., Flagan, R. C., and Seinfeld, J. H.: Organic aerosol formation from the oxidation of biogenic hydrocarbons, J. Geophys. Res., 104, 3555-3567, 1999.

Gysel, M., McFiggans, G. B., and Coe, H.: Inversion of tandem differential mobility analyser (TDMA) measurements, J. Aerosol Sci., 40, 134-151, 2009.

Hamilton, J. F., Lewis, A. C., Carey, T. J., and Wenger, J. C.: Characterization of Polar Compounds and Oligomers in Secondary Organic Aerosol Using Liquid Chromatography Coupled to Mass Spectrometry, Anal. Chem., 80, 474-480, 2008.

Hamilton, J. F., Alfarra, M. Rami, Wyche, K. P., Ward, M. W., Lewis, A. C., McFiggans, G. B., Good, N., Monks, P. S., Carr, T., White, I. R., and Purvis, R. M.: Investigating the use of secondary organic aerosol as seed particles in simulation 
chamber experiments, Atmos. Chem. Phys., 11, 5917-5929, doi:10.5194/acp-11-5917-2011, 2011.

Hansen, U. and Seufert, G.: Temperature and light dependence of beta-caryophyllene emission rates, J. Geophys. Res., 108, 4801, doi:10.1029/2003jd003853, 2003.

Helmig, D., Ortega, J., Duhl, T., Tanner, D., Guenther, A., Harley, P., Wiedinmyer, C., Milford, J., and Sakulyanontvittaya, T.: Sesquiterpene Emissions from Pine Trees - Identifications, Emission Rates and Flux Estimates for the Contiguous United States, Environ. Sci. Technol., 41, 1545-1553, 2007.

Jaoui, M., Leungsakul, S., and Kamens, R. M.: Gas and particle products distribution from the reaction of beta-caryophyllene with ozone, J. Atmos. Chem., 45, 261-287, 2003.

Jaoui, M., Lewandowski, M., Kleindienst, T. E., Offenberg, J. H., and Edney, E. O.: beta-caryophyllinic acid: An atmospheric tracer for beta-caryophyllene secondary organic aerosol, Geophys. Res. Lett., 34, L05816, doi:10.1029/2006g1028827, 2007.

Jenkin, M. E., Wyche, K. P., Evans, C. J., Carr, T., Monks, P. S., Alfarra, M. R., Barley, M. H., McFiggans, G. B., Young, J. C., and Rickard, A. R.: Development and chamber evaluation of the MCM v3.2 degradation scheme for beta-caryophyllene, Atmos. Chem. Phys., 12, 5275-5308, doi:10.5194/acp-12-52752012, 2012.

Jimenez, J. L., Canagaratna, M. R., Donahue, N. M., Prevot, A. S. H., Zhang, Q., Kroll, J. H., DeCarlo, P. F., Allan, J. D., Coe, H., Ng, N. L., Aiken, A. C., Docherty, K. S., Ulbrich, I. M., Grieshop, A. P., Robinson, A. L., Duplissy, J., Smith, J. D., Wilson, K. R., Lanz, V. A., Hueglin, C., Sun, Y. L., Tian, J., Laaksonen, A., Raatikainen, T., Rautiainen, J., Vaattovaara, P., Ehn, M., Kulmala, M., Tomlinson, J. M., Collins, D. R., Cubison, M. J., E, Dunlea, J., Huffman, J. A., Onasch, T. B., Alfarra, M. R., Williams, P. I., Bower, K., Kondo, Y., Schneider, J., Drewnick, F., Borrmann, S., Weimer, S., Demerjian, K., Salcedo, D., Cottrell, L., Griffin, R., Takami, A., Miyoshi, T., Hatakeyama, S., Shimono, A., Sun, J. Y., Zhang, Y. M., Dzepina, K., Kimmel, J. R., Sueper, D., Jayne, J. T., Herndon, S. C., Trimborn, A. M., Williams, L. R., Wood, E. C., Middlebrook, A. M., Kolb, C. E., Baltensperger, U., and Worsnop, D. R.: Evolution of Organic Aerosols in the Atmosphere, Science, 326, 1525-1529, doi:10.1126/science.1180353, 2009

Kanawati, B., Herrmann, F., Joniec, S., Winterhalter, R., and Moortgat, G. K.: Mass spectrometric characterization of $\beta$ caryophyllene ozonolysis products in the aerosol studied using an electrospray triple quadrupole and time-of-flight analyzer hybrid system and density functional theory, Rapid Commun. Mass Sp., 22, 165-186, 2008.

Kleindienst, T. E., Jaoui, M., Lewandowski, M., Offenberg, J. H., Lewis, C. W., Bhave, P. V., and Edney, E. O.: Estimates of the contributions of biogenic and anthropogenic hydrocarbons to secondary organic aerosol at a southeastern US location, Atmos. Environ., 41, 8288-8300, 2007.

König, G., Brunda, M., Puxbaum, H., Hewitt, C. N., Duckham, S. C., and Rudolph, J.: Relative contribution of oxygenated hydrocarbons to the total biogenic VOC emissions of selected midEuropean agricultural and natural plant species, Atmos. Environ., 29, 861-874, 1995.

Lanz, V. A., Alfarra, M. R., Baltensperger, U., Buchmann, B., Hueglin, C., and Prévôt, A. S. H.: Source apportionment of submicron organic aerosols at an urban site by factor analytical mod- elling of aerosol mass spectra, Atmos. Chem. Phys., 7, 15031522, doi:10.5194/acp-7-1503-2007, 2007.

Lee, A., Goldstein, A. H., Keywood, M. D., Gao, S., Varutbangkul, V., Bahreini, R., Ng, N. L., Flagan, R. C., and Seinfeld, J. H.: Gas-phase products and secondary aerosol yields from the ozonolysis of ten different terpenes, J. Geophys. Res., 111, D07302, doi:07310.01029/02005JD006437, 2006a.

Lee, A., Goldstein, A. H., Kroll, J. H., Ng, N. L., Varutbangkul, V., Flagan, R. C., and Seinfeld, J. H.: Gas-phase products and secondary aerosol yields from the photooxidation of 16 different terpenes, J. Geophys. Res., 111, D17305, doi:17310.11029/12006JD007050, 2006b.

Lewandowski, M., Jaoui, M., Offenberg, J. H., Kleindienst, T. E., Edney, E. O., Sheesley, R. J., and Schauer, J. J.: Primary and Secondary Contributions to Ambient PM in the Midwestern United States, Environ. Sci. Technol., 42, 3303-3309, 2008.

Li, Y. J., Chen, Q., Guzman, M. I., Chan, C. K., and Martin, S. T.: Second-generation products contribute substantially to the particle-phase organic material produced by $\beta$-caryophyllene ozonolysis, Atmos. Chem. Phys., 11, 121-132, doi:10.5194/acp11-121-2011, 2011.

Matsunaga, A. and Ziemann, P. J.: Gas-Wall Partitioning of Organic Compounds in a Teflon Film Chamber and Potential Effects on Reaction Product and Aerosol Yield Measurements, Aerosol Sci. Technol., 44, 881-892, 2010.

McFiggans, G., Turner, F., Alfarra, M. R., Coe, H., Good, N., Hamilton, J. F., Kift, R., Monks, P., Smedley, A., Webb, A., Williams, T., and Wyche, K.: A chamber facility for studying the composition, chemistry, physical properties and significance of atmospheric aerosols, Atmos. Meas. Tech., in preparation, 2012.

Misztal, P. K., Nemitz, E., Langford, B., Di Marco, C. F., Phillips, G. J., Hewitt, C. N., MacKenzie, A. R., Owen, S. M., Fowler, D., Heal, M. R., and Cape, J. N.: Direct ecosystem fluxes of volatile organic compounds from oil palms in South-East Asia, Atmos. Chem. Phys., 11, 8995-9017, doi:10.5194/acp-11-89952011, 2011.

Nannoolal, Y., Rarey, J., Ramjugernath, D., and Cordes, W.: Estimation of pure component properties Part 1. Estimation of the normal boiling point of non-electrolyte organic compounds via group contributions and group interactions, Fluid Phase Equilibr., 226, 45-63, 2004.

Nannoolal, Y., Rarey, J., and Ramjugernath, D.: Estimation of pure component properties Part 3. Estimation of the vapor pressure of non-electrolyte organic compounds via group contributions and group interactions, Fluid Phase Equilibr., 269, 117-133, 2008.

Ng, N. L., Kroll, J. H., Keywood, M. D., Bahreini, R., Varutbangkul, V., Flagan, R. C., Seinfeld, J. H., Lee, A., and Goldstein, A. H.: Contribution of first- versus second-generation products to secondary organic aerosols formed in the oxidation of biogenic hydrocarbons, Environ. Sci. Technol., 40, 2283-2297, 2006.

Ng, N. L., Canagaratna, M. R., Zhang, Q., Jimenez, J. L., Tian, J., Ulbrich, I. M., Kroll, J. H., Docherty, K. S., Chhabra, P. S., Bahreini, R., Murphy, S. M., Seinfeld, J. H., Hildebrandt, L., Donahue, N. M., DeCarlo, P. F., Lanz, V. A., Prévôt, A. S. H., Dinar, E., Rudich, Y., and Worsnop, D. R.: Organic aerosol components observed in Northern Hemispheric datasets from Aerosol Mass Spectrometry, Atmos. Chem. Phys., 10, 46254641, doi:10.5194/acp-10-4625-2010, 2010. 
Nørgaard, A. W., Nøjgaard, J. K., Clausen, P. A., and Wolkoff, P.: Secondary ozonides of substituted cyclohexenes: A new class of pollutants characterized by collision-induced dissociation mass spectrometry using negative chemical ionization, Chemosphere, 70, 2032-2038, 2008.

Parshintsev, J., Nurmi, J., Kilpeläinen, I., Hartonen, K., Kulmala, M., and Riekkola, M.-L.: Preparation of $\beta$-caryophyllene oxidation products and their determination in ambient aerosol samples, Anal. Bioanal. Chem., 390, 913-919, 2008.

Petters, M. D. and Kreidenweis, S. M.: A single parameter representation of hygroscopic growth and cloud condensation nucleus activity, Atmos. Chem. Phys., 7, 1961-1971, doi:10.5194/acp-71961-2007, 2007.

Petters, M. D. and Kreidenweis, S. M.: A single parameter representation of hygroscopic growth and cloud condensation nucleus activity - Part 2: Including solubility, Atmos. Chem. Phys., 8, 6273-6279, doi:10.5194/acp-8-6273-2008, 2008.

Topping, D. O., Barley, M. H., and McFiggans, G.: The sensitivity of Secondary Organic Aerosol component partitioning to the predictions of component properties - Part 2: Determination of particle hygroscopicity and its dependence on "apparent" volatility, Atmos. Chem. Phys., 11, 7767-7779, doi:10.5194/acp-11-77672011, 2011.

Turlings, T. C. and Tumlinson, J. H.: Systemic release of chemical signals by herbivore-injured corn, P. Natl. Acad. Sci., 89, 83998402, 1992.

Varutbangkul, V., Brechtel, F. J., Bahreini, R., Ng, N. L., Keywood, M. D., Kroll, J. H., Flagan, R. C., Seinfeld, J. H., Lee, A., and Goldstein, A. H.: Hygroscopicity of secondary organic aerosols formed by oxidation of cycloalkenes, monoterpenes, sesquiterpenes, and related compounds, Atmos. Chem. Phys., 6, 23672388, doi:10.5194/acp-6-2367-2006, 2006.
Williams, P. I., McFiggans, G., and Gallagher, M. W.: Latitudinal aerosol size distribution variation in the Eastern Atlantic Ocean measured aboard the FS-Polarstern, Atmos. Chem. Phys., 7, 2563-2573, doi:10.5194/acp-7-2563-2007, 2007.

Winklmayr, W., Reischl, G. P., Lindner, A. O., and Berner, A.: A new electromobility spectrometer for the measurement of aerosol size distributions in the size range from 1 to $1000 \mathrm{~nm}$, J. Aerosol Sci., 22, 289-296, 1991.

Winterhalter, R., Herrmann, F., Kanawati, B., Nguyen, T. L., Peeters, J., Vereecken, L., and Moortgat, G. K.: The gas-phase ozonolysis of $\beta$-caryophyllene $\left(\mathrm{C}_{15} \mathrm{H}_{24}\right)$. Part I: an experimental study, Phys. Chem. Chem. Phys., 11, 4152-4172, 2009.

Wyche, K. P., Blake, R. S., Willis, K. A., Monks, P. S., and Ellis, A. M.: Differentiation of isobaric compounds using chemical ionization reaction mass spectrometry, Rapid Commun. Mass Sp., 19, 3356-3362, 2005.

Wyche, K. P., Blake, R. S., Ellis, A. M., Monks, P. S., Brauers, T., Koppmann, R., and Apel, E. C.: Technical Note: Performance of Chemical Ionization Reaction Time-of-Flight Mass Spectrometry (CIR-TOF-MS) for the measurement of atmospherically significant oxygenated volatile organic compounds, Atmos. Chem. Phys., 7, 609-620, doi:10.5194/acp-7-609-2007, 2007. 